\title{
Development of the CREATE Inventory in Support of Integrated Climate and Air Quality Modeling for Asia
}

\author{
Jung-Hun Woo ${ }^{1}$, Younha Kim ${ }^{1,2, * \mathbb{C}}$, Hyeon-Kook Kim ${ }^{3}{ }^{\mathbb{D}}$, Ki-Chul Choi ${ }^{4}$, Jeong-Hee Eum ${ }^{5}$, \\ Jae-Bum Lee ${ }^{6}$, Jae-Hyun Lim ${ }^{6}$, Jiyoung Kim ${ }^{6}$ and Miae Seong ${ }^{6}$ \\ 1 Department of Technology Fusion Engineering, College of Engineering, Konkuk University, \\ Seoul 05029, Korea; jwoo@konkuk.ac.kr \\ 2 International Institute for Applied Systems Analysis, 2361 Laxenburg, Austria \\ 3 School of Urban and Environmental Engineering, Ulsan National Institute of Science and Technology, \\ Ulsan 44919, Korea; hyeonkook@unist.ac.kr \\ 4 Korea Environment Institute, Sejong 30147, Korea; minic3000@gmail.com \\ 5 College of Agriculture and Life Science, Kyungpook National University, Daegu 41566, Korea; \\ eumjh@knu.ac.kr \\ 6 National Institute of Environmental Research, Incheon 22689, Korea; gercljb@korea.kr (J.-B.L.); \\ dr4earth@korea.kr (J.-H.L.); jykim77@korea.kr (J.K.); smatina@korea.kr (M.S.) \\ * Correspondence: kimya@iiasa.ac.at
}

Received: 26 August 2020; Accepted: 19 September 2020; Published: 24 September 2020

\begin{abstract}
A bottom-up emissions inventory is one of the most important data sets needed to understand air quality (AQ) and climate change (CC). Several emission inventories have been developed for Asia, including Transport and Chemical Evolution over the Pacific (TRACE-P), Regional Emission Inventory in Asia (REAS), and Inter-Continental Chemical Transport Experiment (INTEX) and, while these have been used successfully for many international studies, they have limitations including restricted amounts of information on pollutant types and low levels of transparency with respect to the polluting sectors or fuel types involved. To address these shortcomings, we developed: (1) a base-year, bottom-up anthropogenic emissions inventory for Asia, using the most current parameters and international frameworks (i.e., the Greenhouse gas-Air pollution INteractions and Synergies (GAINS) model); and (2) a base-year, natural emissions inventory for biogenic and biomass burning. For (1), we focused mainly on China, South Korea, and Japan; however, we also covered emission inventories for other regions in Asia using data covering recent energy/industry statistics, emission factors, and control technology penetration. The emissions inventory (Comprehensive Regional Emissions inventory for Atmospheric Transport Experiment (CREATE)) covers 54 fuel classes, 201 subsectors, and 13 pollutants, namely $\mathrm{SO}_{2}, \mathrm{NO}_{\mathrm{x}}, \mathrm{CO}$, non-methane volatile organic compounds (NMVOC), $\mathrm{NH}_{3}, \mathrm{OC}, \mathrm{BC}, \mathrm{PM}_{10}, \mathrm{PM}_{2.5}, \mathrm{CO}_{2}, \mathrm{CH}_{4}, \mathrm{~N}_{2} \mathrm{O}$, and $\mathrm{Hg}$. For the base-year natural emissions inventory, the Model of Emissions of Gases and Aerosols from Nature (MEGAN) and BlueSky-Asia frameworks were used to estimate biogenic and biomass burning emissions, respectively. Since the CREATE emission inventory was designed/developed using international climate change/air quality (CC/AQ) assessment frameworks, such as GAINS, and has been fully connected with the most comprehensive emissions modeling systems- such as the US Environmental Protection Agency (EPA) Chemical Manufacturing Area Source (CMAS) system-it can be used to support various climate and AQ integrated modeling studies, both now and in the future.
\end{abstract}

Keywords: Asia; emissions inventory; air pollutants; greenhouse gases; anthropogenic emissions; biogenic emissions 


\section{Introduction}

In recent decades, Asia has become increasingly populous, and its economies have grown rapidly, to the extent that East Asia has become the largest emission region in the world due to this large population and the increased energy use caused by its economic growth. From the perspective of the global atmospheric environment, Asia is a critical source of air pollution, and this has become a more serious issue here than in other regions-and lately has begun to receive international attention [1-3].

This problem can be resolved through long-term joint efforts and adoption of best practices, and this approach needs to be supported by objective and scientific data. Systematic tracking of air pollution sources and emissions data organization forms the most effective basis for understanding air pollution processes and deriving policy solutions. This includes collating pollutant emissions by region, sector, and fuel-type, within a comprehensive anthropogenic emissions inventory.

Several emissions inventories have been developed covering Asia; these include TRACE-P (Transport and Chemical Evolution over the Pacific) [4], INTEX-B (Intercontinental Chemical Transport Experiment-Phase B) [5], REAS (Regional Emission inventory in Asia) [2], and EDGAR (Emission Database for Global Atmospheric Research) [6]. Two methods have been used to develop these emissions inventories; the first method uses fundamental data, such as energy use activities, emission factors, and controlling policies, and the second method assembles a mosaic of emissions inventories from different countries or regions. The first method is more structural and informative, as it includes most of the information necessary to understand the socioeconomic, technological, and policy background applicable over the domain—although it has the drawback that limited data are available for some countries and regions. The second method is advantageous because it provides better total emissions estimates for developed countries/regions; however, it can be limited by the amount of fundamental information needed to estimate emissions.

As Asian countries are at various developmental stages, inventory methodologies must be equipped to reflect their rapid socioeconomic changes and policy initiatives. If this can be achieved, while it may not lead to the most accurate emissions estimates, it can represent a system that explains the current situation, predict likely future emissions scenarios, and can be applied to air quality (AQ) studies. Fundamentally, building an integrated emissions modeling inventory can improve both air pollution predictability and climate change (CC) modeling accuracy.

Biogenic emissions play an important role in regional AQ and global atmospheric chemistry. Open biomass burning emissions are a major source of air pollution and can influence global CC through both greenhouse gases (GHGs) and aerosols emissions and vegetation cover losses. Information on natural emission sources is generally quite poor because most emission inventory studies have primarily targeted anthropogenic emissions.

In response to these issues, we developed the Comprehensive Regional Emissions Inventory for Atmospheric Transport Experiment (CREATE) to cover Asian emissions and to support scientific studies and policy development in the region. The CREATE inventory was developed using activities, emission factors, and controls, as these were helpful in estimating not only base year emissions but also present and future year emission scenarios. Our objective was to design and develop an inventory scheme that provides better support for AQ modeling and which can be operated in concert with the Sparse Matrix Operator Kernel Emissions for Asia (SMOKE-Asia) emissions processing system [7]. CREATE includes anthropogenic, biogenic, and biomass burning emissions.

\section{Methodology and Key Parameters}

\subsection{Anthropogenic Emissions}

\subsubsection{GAINS Framework}

Our emissions calculations were developed using the Greenhouse Gas and Air Pollution Interactions and Synergies-Asia (GAINS-Asia) model (http://gains.iiasa.ac.at). GAINS was launched 
in 2006 as an extension to the Regional Air Pollution and Simulation (RAINS) model, which had been used to assess cost-effective response strategies for combating air pollution elements such as fine particulates and ground-level ozone. GAINS provides an authoritative framework for assessing strategies for reducing multiple air pollutant GHG emissions, with the objective of minimizing their negative effects on human health, ecosystems, and climate change (CC), using a least-cost approach.

For each pollutant, GAINS can be applied to estimate emissions based on activity data, uncontrolled emission factors, and emission control measure removal efficiencies, as well as the extent to which such measures have been implemented. For a given country, $i$, and pollutant, $p$, considered in a study, this is achieved using Equation (1) [8]:

$$
E_{i, p}=\sum_{k} \sum_{m} A_{i, k} \cdot e f_{i, k, m, p} \cdot x_{i, k, m, p}
$$

where, $i, k, m$, and $p$ represent the region, activity type, abatement measure, and pollutant, respectively. $E_{p}$ stands for the emission of pollutant $p, A_{i, k}$ represents activity data of type $k$ in region $i, e f_{I, k, m, p}$ stands for the emission factor for pollutant $p$ in region $i$ for activity $k$, after application of control measure $m$ (where $m$ includes the "no control" situation), and $x_{I, k, m, p}$ stands for penetration of region $i$ by control measure $m$ for pollutant $p$ from activity $k$.

This approach incorporates emissions reduction calculation by changing each input parameter and/or making minor structural changes to ensure that the GAINS framework emissions data simplifies evaluation of emission changes as a result of socioeconomic and/or environmental policies.

\subsubsection{Activity Data}

Input parameter formats and methodologies generally differ from country to country. For our modeling, activity data were obtained mostly from World Energy Balance statistics produced by the International Energy Agency (IEA) [9], while in some cases (China, S. Korea, N. Korea, and Japan), official national data were used.

Activity data incorporated into the CREATE inventory, included IEA statistics for the whole of the research domain, the 2010 Energy Statistical Yearbook for China (CESY 2010) [10], the Clean Air Policy Support System (CAPSS) [11] for S. Korea, the Japan Statistical Yearbook (JSY) [12], and several domestic documents released by S. Korea for N. Korea. United Nations (UN) Energy Statistics Database (UN, 2011) [13] energy balance data were used for some countries not covered by IEA data, and non-energy activity data were collected from various international, national, and regional statistics sources, from previous studies, and from official UN Statistics Division documents.

\subsubsection{Emission Factors and Control Technologies}

We used GAINS-Asia emission factors and removal efficiencies as default data where local information was absent, and updated CREATE by including recent regional/national control policies that could be sourced from the literature. For S. Korea, we achieved these updates using activity, emissions, and removal factors published in the CAPSS 2010 official emissions inventory. We viewed the quality of N. Korean emission input-related data as being rather uncertain due to the difficulty in accessing relevant information, and so derived N. Korea input parameters by extrapolating gross domestic product (GDP), population, and industrial activity indexes from S. Korea into N. Korea.

China is the biggest regional energy consumer; however, it has aggressively applied various environmental protection policies. To capture their effects, we reviewed relevant literature (B. Zhao et al., 2013 [14]; Zhang et al., 2009 [5]; Hong et al., 2012 [15]; Y. Zhao et al., 2010 [16]; Lei et al., 2011 [17]; Y. Zhao et al., 2012 [18]) to update the characterization of input parameters, such as removal efficiencies and control technology penetration rates, in the GAINS model [19]. As an example, the initial input parameters in GAINS-Asia and updated flue gas desulfurization (FGD) technology penetration information have been presented in Figure 1, where the revised information shows that most Chinese provinces have achieved high improvement implementation rates. 


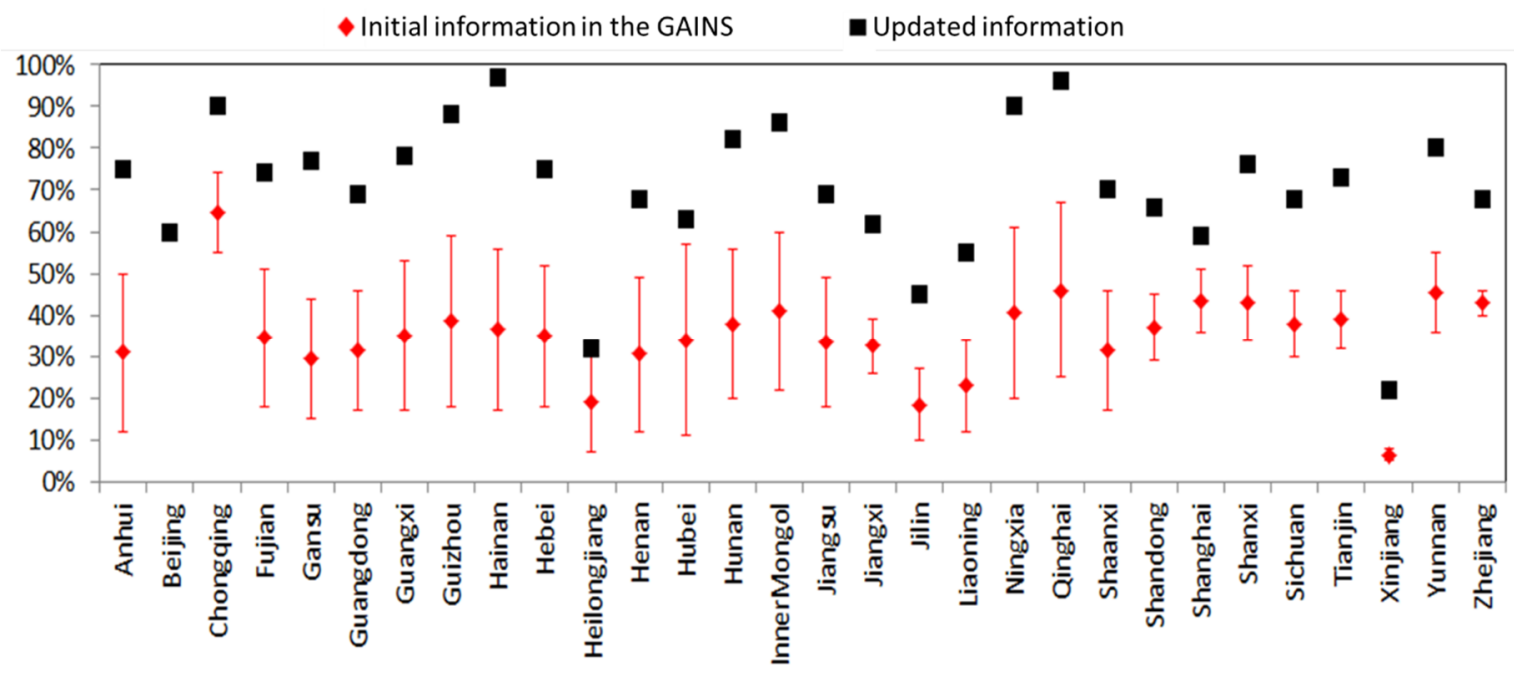

Figure 1. Updated flue gas desulfurization control technology penetration in the Chinese power and industry sector. Initial information was sourced from the United Nations Environment Program (UNEP) scenario in the Greenhouse Gas-Air Pollution Interactions and Synergies (GAINS) model.

\subsection{Natural Emissions}

\subsubsection{Biogenic Emissions: The MEGAN Model}

Biogenic volatile organic compounds (BVOCs) emitted by plants are important in emission and air pollution research, as they are significant contributors of secondary air pollutants, including ozone and secondary fine particles [20-22].

Previous studies on global BVOC emissions (e.g., Guenther et al., 1995; Intergovermental Panel on Climate Change (IPCC), 2007 [23,24]) have reported that they exceed anthropogenic source emissions. Among BVOCs, isoprene $\left(\mathrm{C}_{5} \mathrm{H}_{8}\right)$ has been noted as the dominant chemical compound, accounting for up to $50 \%$ of total BVOCs [23]. BVOCs affect the formation of secondary organic aerosols (SOAs) and tropospheric ozone, as well as radiative forcing, which can influence not only the air quality but also the climate [25-27]. This implies that accurately estimating BVOC atmospheric emissions is important if their role in chemical transport models and their climatic impacts are to be accurately represented. BVOC emissions are often not listed in emissions inventories or have been simply estimated when needed as inputs into AQ modeling studies.

In this study, we used the Model of Emissions of Gases and Aerosols from Nature (MEGAN) v2.04 to estimate BVOC emissions and develop BVOC emissions inventories for Asia. MEGAN is a modeling framework for estimating temporal and spatial emission rates of chemical compounds from the vegetation in the terrestrial ecosystems to the atmosphere $[28,29]$. In general, the equation for calculating natural vegetation emission is as shown in Equation (2):

$$
F_{i}=\gamma_{i} \sum \varepsilon_{i, j} \chi_{j}
$$

where $F_{\mathrm{i}}$ represents emissions of chemical species $i\left(\mathrm{as} \mu \mathrm{g} / \mathrm{m}^{2} \mathrm{~h}^{-1}\right), \gamma_{i}$ denotes emission activity for chemical species $i, \varepsilon_{i, j}$ represents the standard emission factor for chemical species $i$ from vegetation type $j$, and $\chi_{j}$ indicates the percentage of vegetation type $j$ occupying a grid square [28].

We prepared vegetation input variables (basically plant functional type (PFT), leaf area index (LAI)), emission factors (EFs), and main metrological variables (TEMP., for temperature, and RAD., for solar radiation)) related to vegetation emissions as input data for calculating BVOC emissions with MEGAN. Meteorological data were estimated using the Weather Research and Forecasting (WRF) model, and EFs were derived using the database of the MEGAN development group released through the community data portal (http://cdp.ucar.edu) maintained by the US National Center for 
Atmospheric Research (NCAR). PFT and LAI database used in this study were developed by using the Moderate Resolution Imaging Spectroradiometer (MODIS) land cover (LC) and leaf area index (LAI) product of the Terra and Aqua satellite sensors, which were recategorized and converted for inputting into MEGAN. Details on the preparation of vegetation input variables (i.e., PFT and LAI) utilizing MODIS LC and LAI products are documented in Kim et al. [30]. Through the implementation of MEGAN using these input variables, we developed gridded BVOC emissions data, and then generated a country-based, annual BVOCs emissions inventory for Asia.

We tried to maintain speciated emissions by two different types of chemical mechanisms (i.e., CB05 and SAPRC99 [31,32]) in order to open a possibility to support multiple possible simulation setups in Chemical Transport Models (CTMs) (Table 1).

Table 1. Modeling Parameters Information.

\begin{tabular}{ccc}
\hline Parameters & Source & Description \\
\hline MEGAN model & 2.04 (US NCAR) & Guenther et al. (2006) [28] \\
Chemical Mechanism & CB05 (1) and SAPRC99 (2) & Yarwood et al. (2005) [31], Carter, W.P.L. (2000) [32] \\
Temperature data & WRF v3.2 (US NCAR) & TEMP2(K) (3) \\
Solar radiation data & WRF v3.2 (US NCAR) & RGRN(W/m2) ${ }^{(4)}$ \\
PFTF & MODIS land cover 2009 & https://wist.echo.nasa.gov/api/ \\
LAI & MODIS LAI 2009 & https://wist.echo.nasa.gov/api/ \\
Emission factor data source & MEGAN EFv2.1 & http://cdp.ucar.edu \\
\hline (1) Carbon Bond (CB05) mechanism, $^{(2)}$ State Air Pollution Research Center 99, ${ }^{(3)}$ Air temperature at 2 m above ground, \\
(4) Solar radiation absorbed at ground.
\end{tabular}

In this study, the simulation with the WRF version 3.2 was conducted on a domain using $60 \mathrm{~km} \times 60 \mathrm{~km}$ horizontal resolution with $148 \times 184$ cells in the horizontal direction and 32 layers in the vertical direction. The 6 hourly NCEP (National Centers for Environmental Prediction) data with $1^{\circ} \times 1^{\circ}$ grid resolution were used for the initial meteorological condition for the WRF simulation. The simulation was conducted over one year. More detailed configuration of WRF is described in Table 2.

Table 2. Configuration of the Weather Research and Forecasting (WRF) model simulation [33].

\begin{tabular}{cc}
\hline Item & Description \\
\hline WRF version & WRFv3.2 \\
Resolution & $60 \mathrm{~km} \times 60 \mathrm{~km}$ \\
Horizontal Number of Grids & $148 \times 184$ \\
Number of Vertical layers & 32 layers \\
& $1^{\circ} \times 1^{\circ}$ and every six hours data from the National \\
Initial Conditions & Centers for Environmental Prediction Final \\
& (NCEP FNL) (http://dss.ucar.edu/datasets/ds083.2/) \\
Topography Data & 30 s USGS \\
Microphysics & WSM6 ${ }^{(1)}$ (WRF Single-Moment 6-Class) \\
longwave radiation & RRTM (Rapid Radiative Transfer Model) scheme \\
shortwave radiation & Dudhia scheme \\
surface-layer options & Monin-Obukhov scheme \\
PBL physics & YSU (2) scheme \\
Cumulus physics & Kain-Fritsch (new Eta) scheme \\
Surface physics & Unified Noah land-surface model \\
\hline (1) Weather Research and Forecasting Single Moment 6, ${ }^{(2)}$ YonSei University.
\end{tabular}

\subsubsection{Biomass Burning Emissions: The BlueSky-Asia Model}

The biomass burning estimation method used in this study was based on the BlueSky model developed by the US Department of Agriculture Forest Service and the US EPA. It was designed to facilitate the production of predictive models for calculating cumulative impacts from smoke 
on $A Q$, and from forest, agricultural, and range fire emissions [34,35]. In this study, we decided to use Fuel Characteristic Classification System (FCCS) data for three fuel loadings mapped in BlueSky, as they provided a more detailed fuel classification structure compared with other database options. Total fuel consumption was estimated using the CONSUME model (which outputs fuel consumption and emissions by combustion phase), and emissions were calculated based on the BlueSky emissions production model. The domain for our biomass emissions inventory covered not only Asia, but also Siberia and parts of central Asia, as these regions have histories of large-scale fires that can affect our target region.

To generate fire and fuel loading information, we used the MCD45A1 MODIS product [36], which provides fire data (Burned-area Product (BAP)) for fuel-loading calculations, as well as land cover information for biomass classification. BAP information is delivered with a relatively high (daily) temporal resolution and medium-scale (500 m grid) spatial resolution; each fire event is represented by one polygon, which contains the number of burned-area pixels detected (total area burned), date of burning, and location. Such polygons were used as inputs for fire event plume-rise calculations and for biomass-burning emission calculations.

We created a new fuel map (using the MODIS land cover data) for the fuel loading process [37,38], and daily emission estimates from each fire were calculated using this process. Emissions from biomass burning were then estimated for 2008 using the developed modeling framework. We linked this output to the SMOKE processing system to generate input emission data for a three-dimensional, chemical transport model. By combining these two tools, open biomass fires could be modeled, and fire emission AQ impact simulations could be improved. The methodology and results associated with the biomass burning part of the CREATE inventory were described in more detail in Choi et al. 2013 [35].

\subsection{Research Framework and Domain Setting}

The overall framework for biomass-burning, anthropogenic, and biogenic emissions estimation is presented in Figure 2.

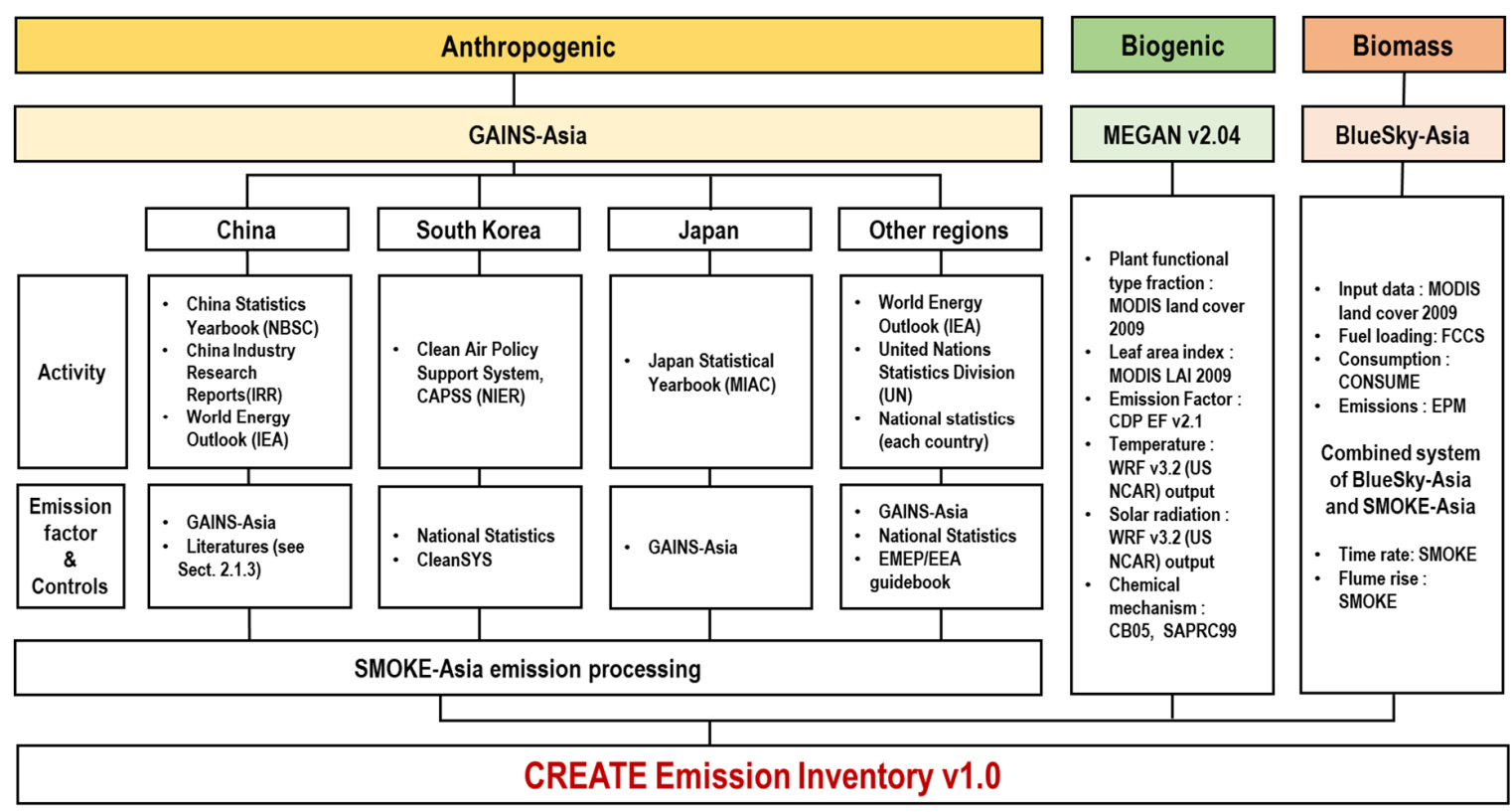

Figure 2. Data and flow used for Comprehensive Regional Emissions Inventory for Atmospheric Transport Experiment (CREATE) inventory development.

Domain, species, and data source information is presented in Table 3. Emissions for 22 countries (99 regions) were compiled in the CREATE inventory, covering the geographical domain shown in Figure 3. 
Table 3. Contents and scope of CREATE inventory.

\begin{tabular}{|c|c|}
\hline Item & Description \\
\hline Domain & 22 countries and 99 regions \\
\hline Countries and region & $\begin{array}{c}\text { Bangladesh(two regions), Bhutan, Brunei Darussalam, } \\
\text { Cambodia, China (32 regions), India (23 regions), } \\
\text { Indonesia (four regions), Japan (six regions), } \\
\text { Democratic People's Republic of Korea, Republic of } \\
\text { Korea (four regions), Laos, Malaysia (three regions), } \\
\text { Mongolia, Myanmar, Nepal, Pakistan (four regions), } \\
\text { Philippines (three regions), Singapore, Sri Lanka, } \\
\text { Taiwan, Thailand (five regions), Vietnam (two } \\
\text { regions) }\end{array}$ \\
\hline Species & $\begin{array}{l}\mathrm{CO}, \mathrm{NO}_{x}, \mathrm{SO}_{2}, \text { Primary } \mathrm{PM}_{10} \text { and } \mathrm{PM}_{2.5}, \text { VOCs, } \mathrm{NH}_{3} \text {, } \\
\qquad \mathrm{CO}_{2}, \mathrm{CH}_{4}, \mathrm{~N}_{2} \mathrm{O}\end{array}$ \\
\hline Sector & $\begin{array}{l}\text { Powerplant, Industry, Residential, Transportation, } \\
\text { Other (54 fuel classes, } 201 \text { Sub-sectors) }\end{array}$ \\
\hline Source & Anthropogenic, Biogenic, Biomass burning \\
\hline $\begin{array}{c}\text { Year } \\
\text { Data Access }\end{array}$ & $\begin{array}{c}2010 \\
\text { http://aisl.konkuk.ac.kr/\#/emission_data/create_ } \\
\text { emission_inventory }\end{array}$ \\
\hline
\end{tabular}

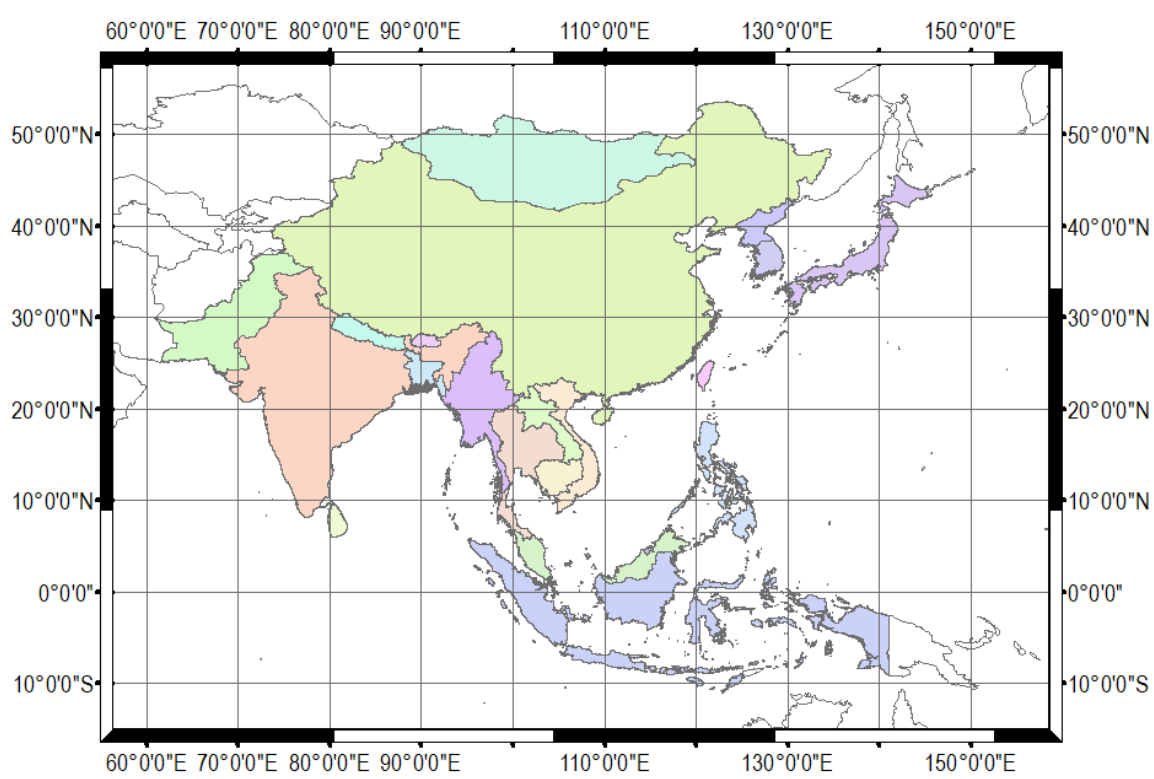

Figure 3. CREATE Inventory Domain.

The main pollutant sources and categories in the CREATE emissions inventory are explained in Table 4. The methodologies and parameters explained in Section 2 were used to estimate emissions for CREATE, and in Section 3, emission estimation results have been discussed as follows: (1) anthropogenic emissions in 2010; (2) natural source emissions; (3) comparisons with other studies; (4) analysis of uncertainty. 
Table 4. Classification of emissions by source.

\begin{tabular}{|c|c|c|c|c|c|c|c|c|c|c|}
\hline & Sector & $\mathrm{SO}_{2}$ & $\mathrm{NO}_{\mathrm{x}} \mathrm{CO}$ & ${ }^{*} \mathbf{P M}_{10}$ & ${ }^{*} \mathbf{P M}_{2.5}$ & NMVOC & $\mathrm{CO}_{2}$ & $\mathrm{~N}_{2} \mathrm{O}$ & $\mathrm{NH}_{3}$ & $\mathrm{CH}_{4}$ \\
\hline Anthropogenic & $\begin{array}{l}\text { Combustion/Non-combustion/ } \\
\text { Agriculture, etc. }\end{array}$ & $\bullet$ & $\bullet$ & $\bullet$ & $\bullet$ & $\bullet$ & $\bullet$ & $\bullet$ & $\bullet$ & $\bullet$ \\
\hline \multirow{2}{*}{ Natural } & Biomass Burning & & $\bullet$ & & $\bullet$ & $\bullet$ & & & & \\
\hline & Biogenic & & $\bullet$ & & & $\bullet$ & & $\bullet$ & $\bullet$ & $\bullet$ \\
\hline
\end{tabular}

\section{Results and Discussion}

\subsection{Asian Anthropogenic Emissions in 2010}

National and regional emissions summaries for each major species by sector in 2010 are presented in Table 5. We estimated total Asian emissions for 2010 as follows: $\mathrm{CH}_{4} 109.4 \mathrm{Tg}$, $\mathrm{CO} 280.5 \mathrm{Tg}$, $\mathrm{CO}_{2} 14.1 \mathrm{Pg}, \mathrm{N}_{2} \mathrm{O} 4.1 \mathrm{Tg}, \mathrm{NH}_{3} 26.4 \mathrm{Tg}, \mathrm{NO}_{\mathrm{x}} 35.3 \mathrm{Tg}, \mathrm{PM}_{10} 37.4 \mathrm{Tg}, \mathrm{PM}_{2.5} 26.7 \mathrm{Tg}, \mathrm{SO}_{2} 46.0 \mathrm{Tg}$, and VOC $45.2 \mathrm{Tg}$-with the emission distribution in each Asian regional group shown in Figure 4. E. Asia contributed between $53 \%$ and $77 \%$ of the total for all Asia, and China's emissions were predominant in not only E. Asia but also across the entire Asia region. S. Asia contributed approximately $25 \%$, on average, and its emissions were dominated by those from India, which made the second-largest contribution to total Asian emissions, following China. S. E. Asia contributed $>15 \%$ to the total VOC and CO emissions and $\sim 10 \%$ of the other pollutant totals. Apart from India, the other S. Asian countries contributed $<5 \%$ of the emissions of most pollutants, although these other S. Asian countries contributed approximately $10 \%$ of the agriculture-related pollutants total $\left(\mathrm{NH}_{3}, \mathrm{CH}_{4}\right.$, and $\left.\mathrm{N}_{2} \mathrm{O}\right)$.

Sectoral emission totals for 2010 for Asia and each region are shown in Figures 5 and 6 respectively. For $\mathrm{SO}_{2}$, large contributions from coal-fired power plants and the manufacturing industry predominated, with power (47\%) and industry $(42 \%)$ being the largest source sectors in Asia. The figures showed that the power sector was the largest emitter (>50\%) in China, India, and other South (OS) Asia, while the industry sector was the largest contributor in $\mathrm{S}$. Korea and Japan. For $\mathrm{NO}_{\mathrm{x}}$, the inventory showed that the power, transport, and industry sectors were important source sectors in all regions. Contrary to $\mathrm{SO}_{2}$ emissions, other East (OE) Asia and S. E. Asia both accounted for $>10 \%$, through the contributions made by their transportation sectors. China and India showed relatively low transportation sector contributions compared with the other regions due to the overwhelming size of their power sector contributions.

For $\mathrm{PM}_{2.5}$, domestic biofuel and coal consumption was high in India, OS Asia, and S. E. Asia, which explained why the residential sector was the dominant $\mathrm{PM}_{2.5}$ emissions contributor, while in $\mathrm{S}$. Korea and Japan the industry and transportation sectors were dominant. For $\mathrm{CO}$, the power sector contributed less than it did to other combustion-related species; this reflected the concept that $\mathrm{CO}$ is mainly emitted from incomplete combustion, and power plants generally have higher combustion efficiencies than those of either smaller industrial facilities or residential cooking and heating equipment. The data showed that residential sectors were the major $\mathrm{CO}$ emitters in most regions, except in S. Korea and Japan. S. Asia, including India, made higher residential sector contributions than other regions, while emissions from transportation were the largest contributor in Japan and S. Korea.

For VOCs, industry, including solvent sources, was the largest source sector in China, S. Korea, and Japan, and was an important source for all VOC species. The residential sector was also a major $\mathrm{CO}$ and VOC contributor, with the exceptions of S. Korea and Japan-mainly as biofuel use is very limited in these countries, which focus mainly on gas fuels in the residential sector, in line with the National Institute of Environmental Research (NIER) 2013 [39], and as reported in Ohara et al. [1]. Transportation is an important CO and VOC source sector, especially in S. E. Asia, due to the high numbers of two- and three-wheeled transportation formats there, as reported in F. Posada et al. [40]. 
$\mathrm{NH}_{3}, \mathrm{NO}_{x}, \mathrm{SO}_{2}$, and $\mathrm{OC}$ emission maps, for 2010, are presented in Figure 7 , at a $0.1^{\circ} \times 0.1^{\circ}$ grid resolution. These maps show quite clearly that the Indian Indo-Gangetic Plain and the Chinese east coast were high emission areas for all pollutants in 2010. $\mathrm{SO}_{2}$ emissions from the Chinese east coast and the central west coast of India were very high, while high $\mathrm{NO}_{\mathrm{x}}$ emission regions were widely distributed across S. Korea, Japan, China, and India, and around the S. E. Asian megacities. In China, high emission regions included the Northeast and the Yangtze and Pearl River deltas.

Table 5. Anthropogenic Emissions of Asia by region (Unit: $\mathrm{Gg} / \mathrm{year}, \mathrm{CO}_{2}$ : Tg/year).

\begin{tabular}{|c|c|c|c|c|c|c|c|c|c|}
\hline Region & $\mathrm{CO}$ & $\mathrm{NO}_{\mathbf{x}}$ & $\mathrm{SO}_{2}$ & $\mathrm{PM}_{2.5}$ & VOC & $\mathrm{NH}_{3}$ & $\mathrm{CO}_{2}$ & $\mathrm{CH}_{4}$ & $\mathrm{~N}_{2} \mathrm{O}$ \\
\hline China (PRC) & 168,698 & 21,211 & 29,855 & 14,969 & 21,913 & 13,492 & 8611 & 46,779 & 2001 \\
\hline Korea(south) & 837 & 1094 & 402 & 111 & 850 & 269 & 585 & 1247 & 28 \\
\hline Japan & 4188 & 1701 & 614 & 175 & 1414 & 308 & 1249 & 1337 & 98 \\
\hline Mongolia & 64 & 58 & 73 & 19 & 20 & 94 & 8 & 316 & 31 \\
\hline Korea (North) & 1462 & 319 & 318 & 281 & 272 & 80 & 103 & 618 & 16 \\
\hline Taiwan (ROC) & 1414 & 440 & 139 & 49 & 402 & 121 & 261 & 568 & 18 \\
\hline E. Asia total & 176,663 & 24,823 & 31,427 & 15,603 & 24,870 & 14,363 & 10,817 & 50,866 & 2192 \\
\hline Brunei & 36 & 16 & 12 & 3 & 41 & 29 & 7 & 62 & 2 \\
\hline Indonesia & 21,019 & 1578 & 1632 & 1539 & 4121 & 830 & 430 & 8534 & 238 \\
\hline Cambodia & 799 & 60 & 28 & 75 & 125 & 74 & 5 & 528 & 10 \\
\hline Laos & 357 & 27 & 21 & 32 & 99 & 56 & 4 & 241 & 5 \\
\hline Myanmar & 2221 & 82 & 32 & 221 & 337 & 340 & 13 & 2078 & 49 \\
\hline Malaysia & 3239 & 519 & 234 & 151 & 936 & 125 & 208 & 1010 & 35 \\
\hline Philippines & 3526 & 316 & 609 & 206 & 883 & 249 & 90 & 1628 & 54 \\
\hline Singapore & 171 & 129 & 130 & 8 & 77 & 23 & 68 & 53 & 38 \\
\hline Thailand & 3432 & 859 & 552 & 354 & 907 & 259 & 277 & 2799 & 72 \\
\hline Vietnam & 6240 & 398 & 373 & 604 & 1017 & 415 & 113 & 3005 & 82 \\
\hline S. E. Asia Total & 41,041 & 3984 & 3623 & 3193 & 8544 & 2400 & 1213 & 19,937 & 585 \\
\hline Bangladesh & 4770 & 183 & 154 & 486 & 745 & 599 & 44 & 3866 & 30 \\
\hline Bhutan & 155 & 9 & 6 & 13 & 29 & 31 & 2 & 104 & 5 \\
\hline India & 47,648 & 5548 & 9508 & 6163 & 9495 & 7162 & 1850 & 26,975 & 1002 \\
\hline Sri Lanka & 1049 & 57 & 67 & 104 & 178 & 44 & 11 & 406 & 12 \\
\hline Nepal & 1967 & 36 & 47 & 188 & 275 & 189 & 7 & 1015 & 32 \\
\hline Pakistan & 7191 & 688 & 1132 & 925 & 1053 & 1568 & 191 & 6334 & 227 \\
\hline S. Asia Total & 62,780 & 6521 & 10,914 & 7879 & 11,775 & 9593 & 2104 & 38,699 & 1308 \\
\hline Total & 280,485 & 35,327 & 45,963 & 26,675 & 45,190 & 26,356 & 14,135 & 109,502 & 4085 \\
\hline
\end{tabular}

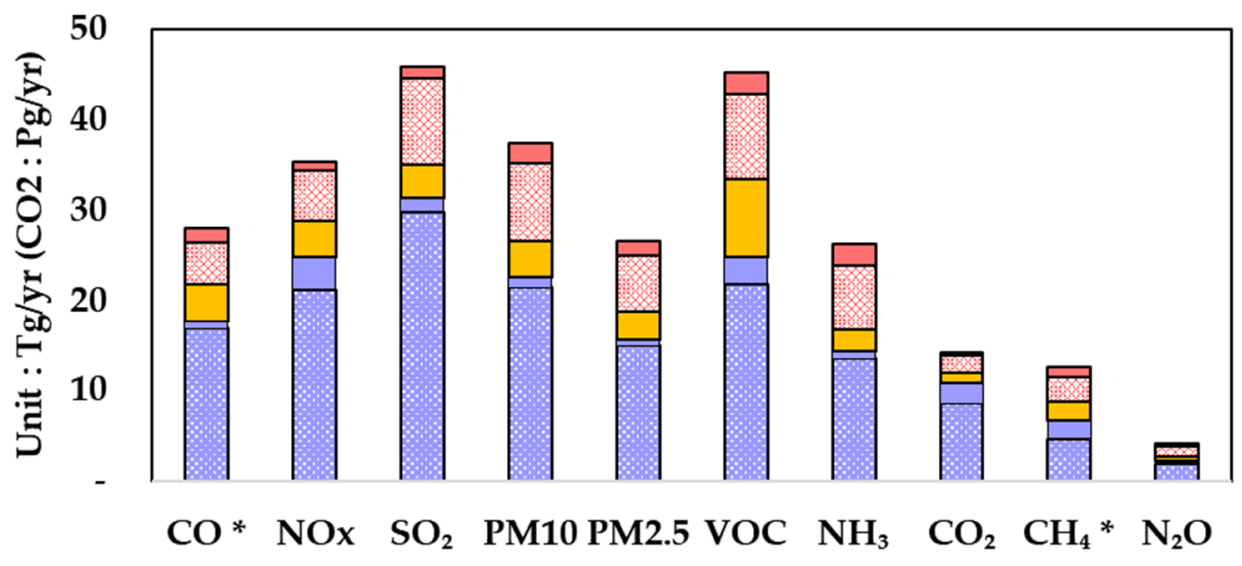

\section{$\square$ China $\square$ Other East Asia $\square$ Southeast Asia $\square$ India $\square$ Other South Asia}

Figure 4. Emissions contributions by region ( ${ }^{*} \mathrm{CO}$ and $\mathrm{CH}_{4}$ figures have been divided by 10$)$. 


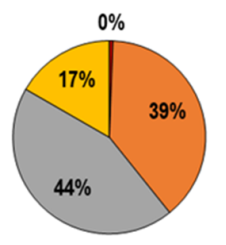

$\mathrm{CO}$

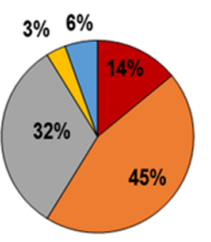

$\mathrm{PM}_{10}$

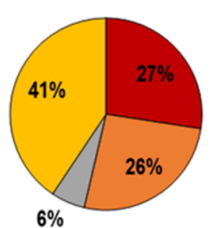

NOx

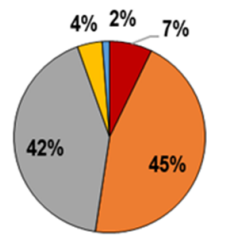

$\mathbf{P M}_{2.5}$

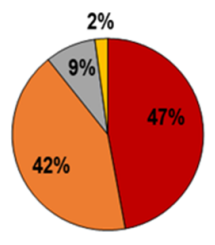

$\mathrm{SO}_{2}$

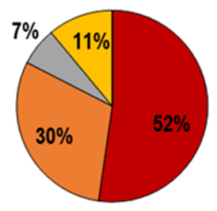

$\mathrm{CO}_{2}$

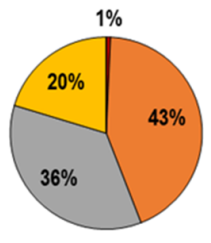

VOC

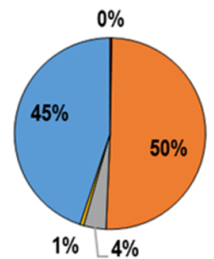

$\mathrm{CH}_{4}$

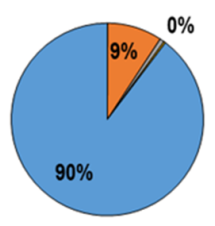

$\mathrm{NH}_{3}$

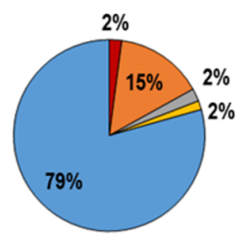

$\mathrm{N}_{2} \mathrm{O}$

$\square$ Power $\square$ Industry $\square$ Residential $\square$ Transportation $\square$ Other

Figure 5. Emissions distribution by sector, in Asia.

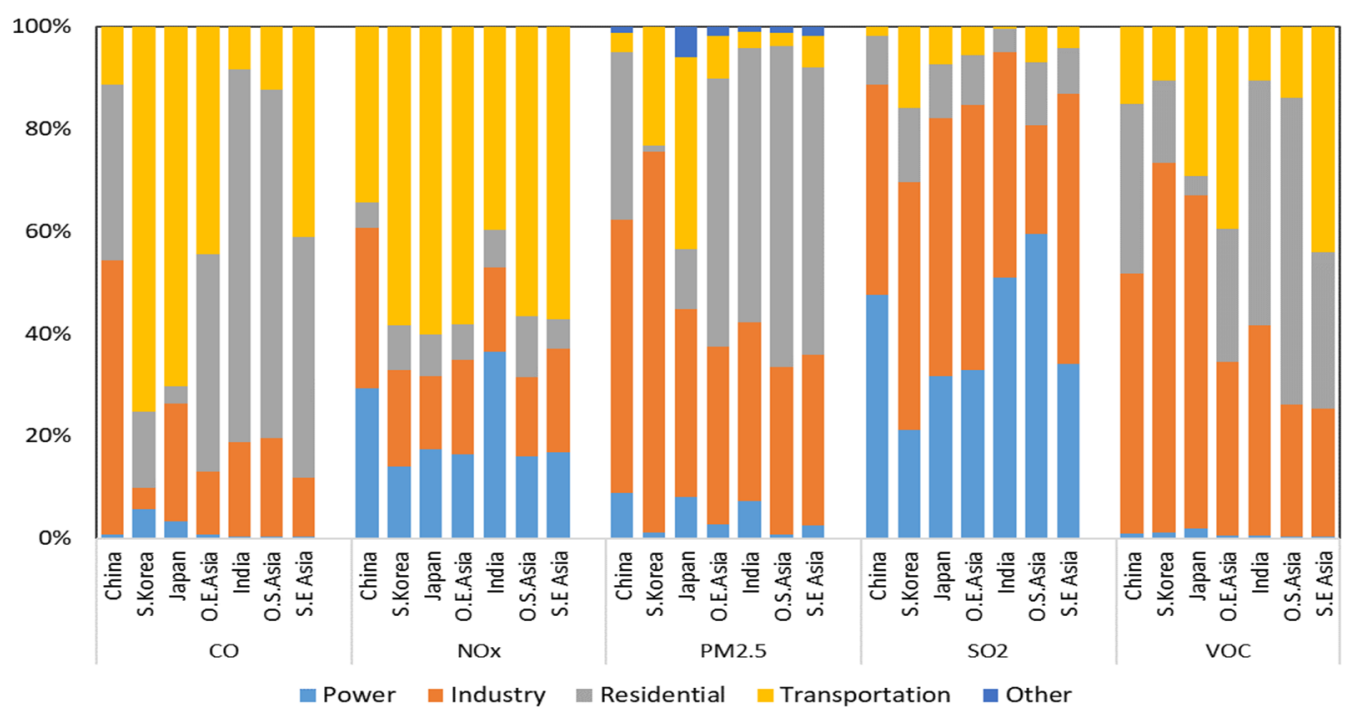

Figure 6. Sectoral emissions distribution by region.

We analyzed pollutant-to-pollutant ratios to understand regional emissions characteristics. Anthropogenic $\mathrm{CO}_{2}$ emission is a good indicator for energy use whereas air pollutants emissions are good indicators for combustion efficiency $(\mathrm{CO})$ and strength of environmental policy-technology measures $\left(\mathrm{NO}_{\mathrm{x}}, \mathrm{SO}_{2}\right)$. Ratio analyses allow control levels to be deduced.

It was apparent from review of the data mapped in Figure 8 that the $\mathrm{SO}_{2} / \mathrm{CO}_{2}, \mathrm{NO}_{\mathrm{x}} / \mathrm{CO}_{2}, \mathrm{CO} / \mathrm{CO}_{2}$, and $\mathrm{PM}_{2.5} / \mathrm{CO}_{2}$ emission ratios were lower in S. Korea and Japan than in other regions. This perhaps reflected the improved emission control measures-such as FGD devices, for $\mathrm{SO}_{2}$ control, and selective catalytic reduction (SCR) technologies for $\mathrm{NO}_{x}$ control—operating there. The most significant regional differences were observed for the $\mathrm{CO} / \mathrm{CO}_{2}$ ratio. $\mathrm{CO}$ emissions result from low combustion efficiencies in the residential sector. Since solid fuels, such as coal or biofuel, are rarely used for cooking and heating in a residential sector, $\mathrm{S}$. Korea and Japan have low $\mathrm{CO}$ emission levels from this sector, with the industry and transportation sectors providing the major $\mathrm{CO}$ emission sources in these two countries. In contrast, coal and biofuels provided a high total energy consumption share in the residential sector in S. E. Asia, O.S Asia, and India. 
We evaluated the CREATE emission inventory by region, using per-capita and GDP metrics, as population and GDP are major driving forces behind anthropogenic emissions, making these parameters good indicators for emission intensity evaluation. GDP figures provided by the World Bank (in USD), as constant purchasing power parity (PPP) [41], were used, and we compared the top four $\mathrm{CO}_{2}$ emitters in Asia for the purposes of this analysis.
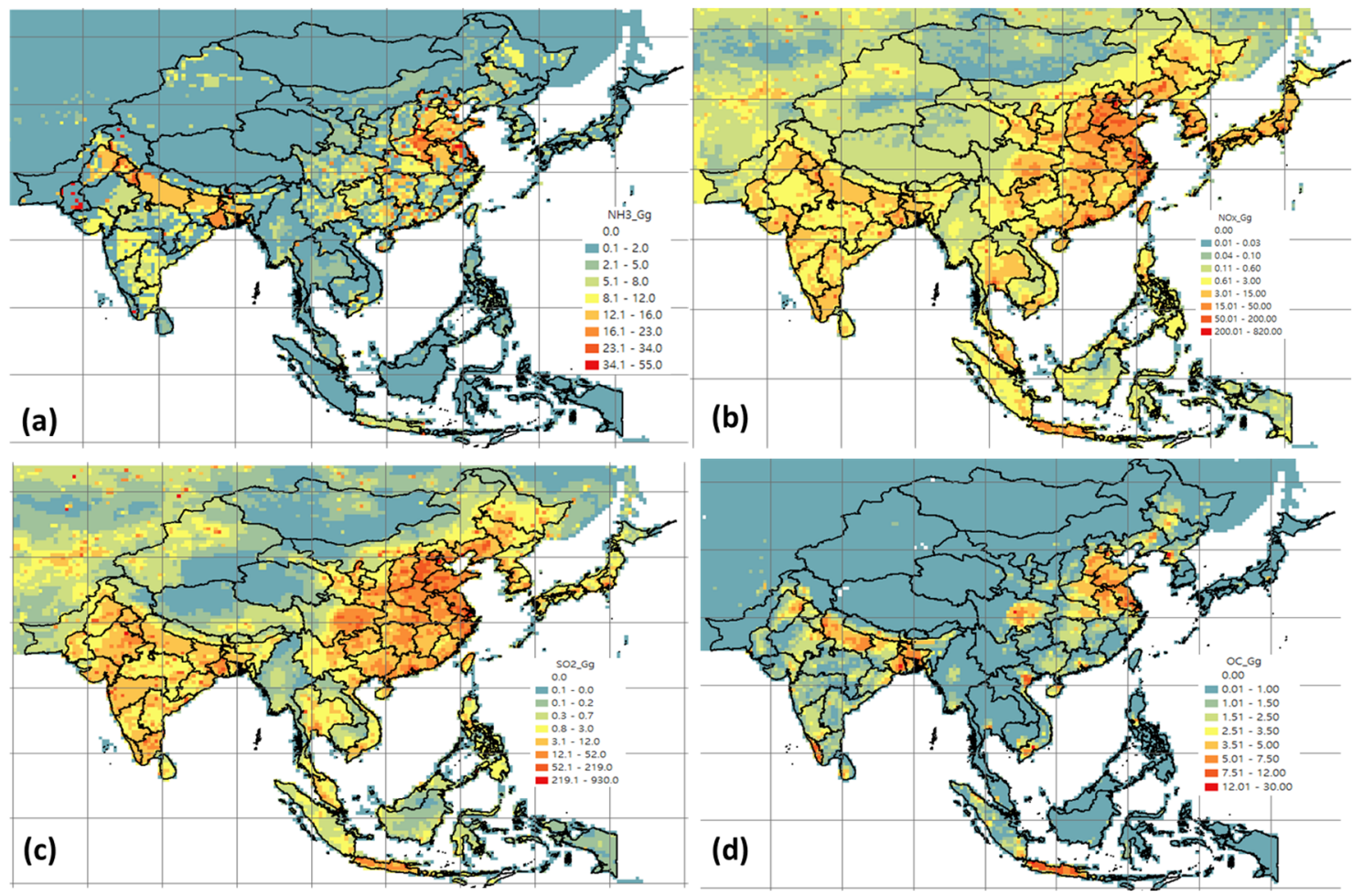

Figure 7. Spatial distribution of selected Asian anthropogenic emissions: (a) $\mathrm{NH}_{3}$; (b) $\mathrm{NO}_{\mathrm{x}}$; (c) $\mathrm{SO}_{2}$; (d) OC.

Review of the estimates shown in Figure 9 indicated that China's emission per GDP unit was the highest for most pollutants, with the exception of $\mathrm{NH}$, with its $\mathrm{NO}_{\mathrm{x}}$ and $\mathrm{SO}_{2}$ emissions per GDP unit being noticeably high, which might indicate higher combustion-related activities in various sectors including power generation and industry. For NH3, India was the highest emitter per GDP unit, which was probably reflected a higher level of agricultural and livestock activities. Japan exhibited the lowest emissions per GDP unit for all pollutants, except $\mathrm{NO}_{x}$, followed by S. Korea.

The data showed quite clearly that $S$. Korea and Japan had low air pollutant emissions per GDP unit-even with high economic activity-demonstrating that effective emissions control technologies were more often applied in these two countries. This can also be seen in the fact that differences in $\mathrm{CO}_{2}$ per GDP unit for each country were significantly less than the differences apparent for other pollutant emissions, as $\mathrm{CO}_{2}$ emissions are mostly dependent on fuel use, rather than on control measures.

Economic development status and industry roles within the global supply train is also a major factor for the differences of ratio. The manufacturing industries with higher energy use and heavier pollution generation tend to migrate from more developed countries to the developing countries to avoid more stringent regulations. 

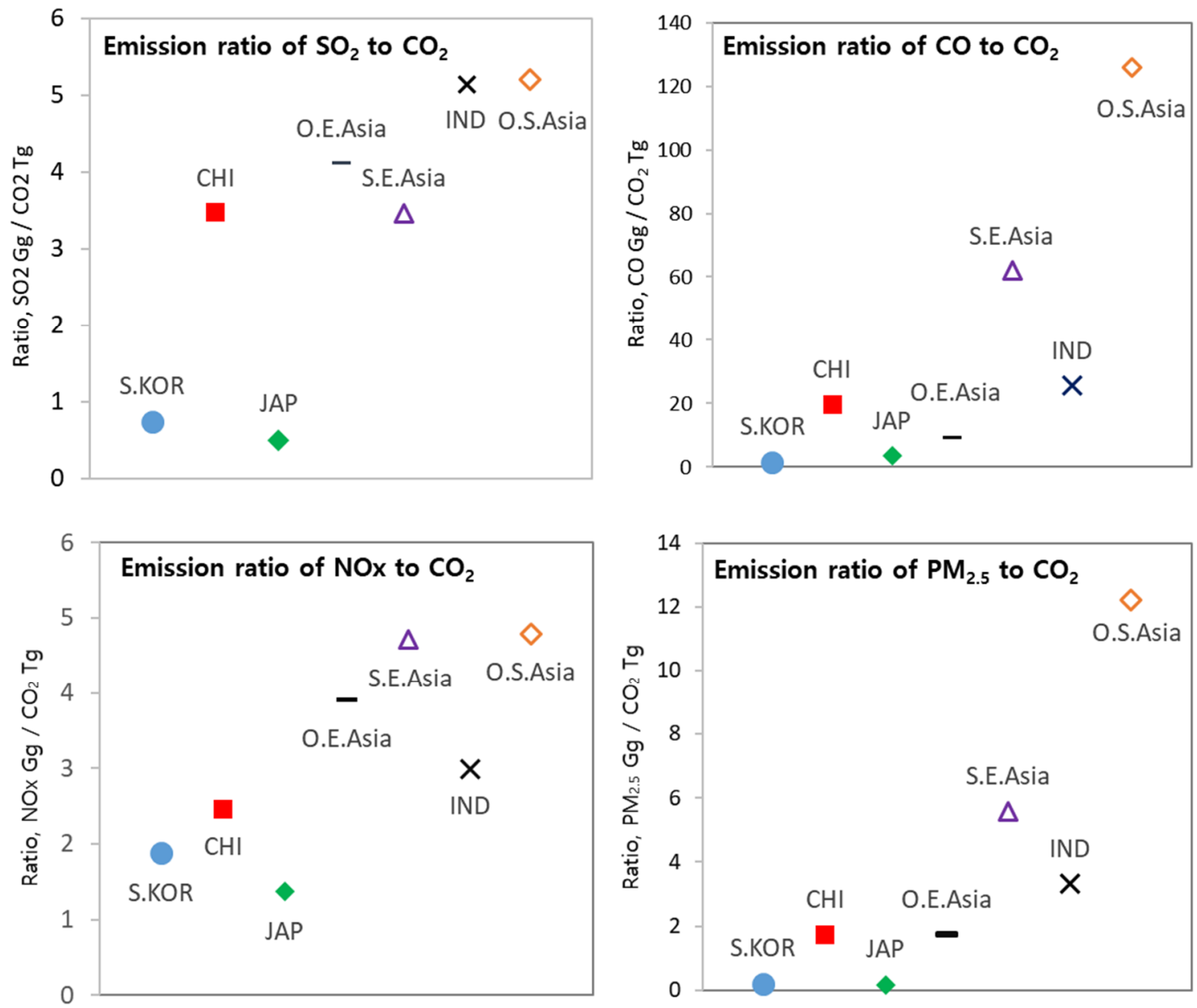

Figure 8. $\mathrm{SO}_{2} / \mathrm{CO}_{2}, \mathrm{NO}_{\mathrm{x}} / \mathrm{CO}_{2}, \mathrm{CO} / \mathrm{CO}_{2}$, and $\mathrm{PM}_{2.5} / \mathrm{CO}_{2}$ emission ratios by region (S.KOR = South Korea; $\mathrm{CHI}=$ China; O.E.Asia $=$ Other East Asia; S.E.Asia = Southeast Asia; IND = India; O.S.Asia = Other South Asia), (X-axis: country or region, Y-axis: emission ratio).

Regional per-capita emissions comparisons, prepared using population data obtained from the World Bank (https://data.worldbank.org/indicator), have been illustrated in Figure 10. The legends O.E.A (for other E. Asia), O.S.A (for other S. Asia), and S.E.A (for S. E. Asia) indicate where the average values represent regional groups. Unlike the per-GDP emissions, S. Korea and Japan show high per-capita $\mathrm{NO}_{\mathrm{x}}$ and VOC emissions, with the high S. Korea emissions (compared with other regions) representing the outcome of higher per-capita energy use-in applications such as more cars and industry-which reflects its more advanced economic development. For $\mathrm{SO}_{2}$ and $\mathrm{PM}_{2.5}$, China showed the highest per-capita emissions, while for $\mathrm{NO}_{\mathrm{x}}$ and NMVOCs China showed levels similar to those of S. Korea and Japan. India showed low per-capita emission levels for all pollutants.

Future per-GDP and per-capita emissions analyses would be expected to show noticeable value changes due to both the ongoing rapid economic growth in India and S. E. Asia and the significant emission reductions achieved by Chinese emissions control policies. 


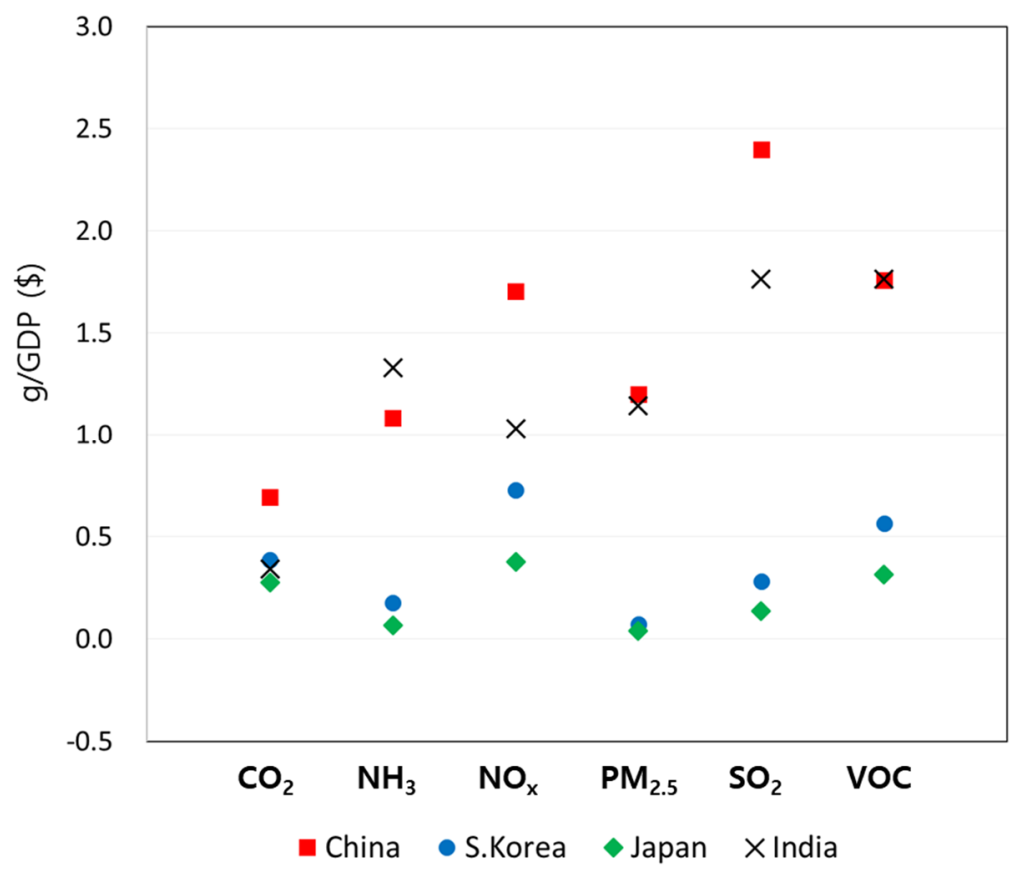

Figure 9. 2010 emissions divided by GDP (as purchasing power parity (PPP)).
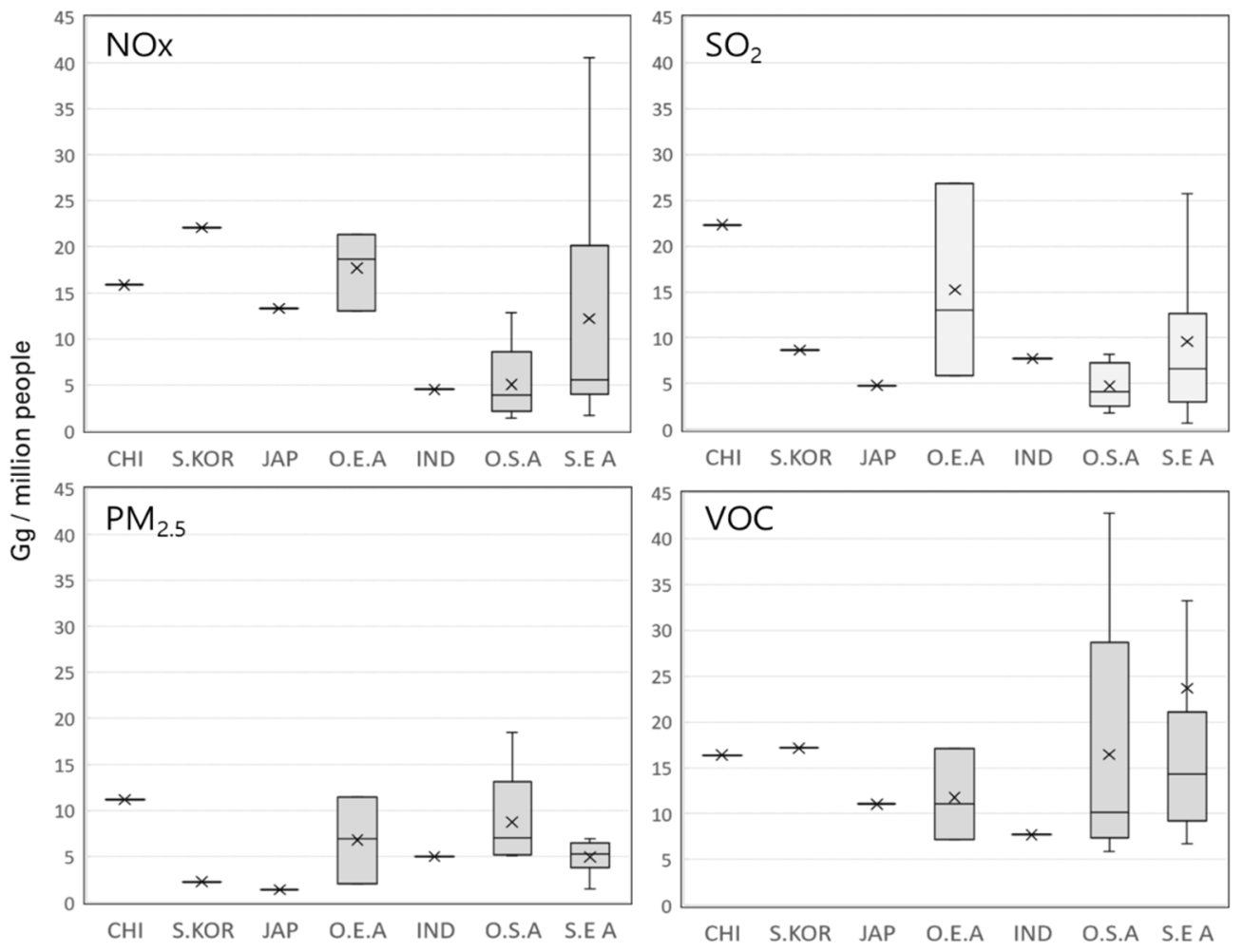

Figure 10. Per-capita emissions by region.

\subsection{Natural Emissions}

\subsubsection{Biogenic Emissions}

Monthly mean biogenic emission data for nine major species-isoprene $\left(\mathrm{C}_{5} \mathrm{H}_{8}\right)$, monoterpene $\left(\mathrm{C}_{10} \mathrm{H}_{16}\right)$, acetaldehyde $\left(\mathrm{CH}_{3} \mathrm{CHO}\right)$, carbon monoxide $(\mathrm{CO})$, ethylene (or ethene) $\left(\mathrm{C}_{2} \mathrm{H}_{4}\right)$, 
ethane $\left(\mathrm{C}_{2} \mathrm{H}_{6}\right)$, formaldehyde $\left(\mathrm{CH}_{2} \mathrm{O}\right)$, methanol $\left(\mathrm{CH}_{3} \mathrm{OH}\right)$, and toluene $\left(\mathrm{C}_{7} \mathrm{H}_{8}\right)$-were estimated for Asia, for 2009, using MEGANv2.04, on a $0.1^{\circ} \times 0.1^{\circ}$ grid. Annual totals for these species are listed by country in Table 6 .

Table 6. Biogenic emissions across the countries in Asia (unit: Tg/year).

\begin{tabular}{ccc}
\hline & Isoprene $\left(\mathbf{C}_{\mathbf{5}} \mathbf{H}_{\mathbf{8}}\right)$ & Monoterpene $\left(\mathbf{C}_{\mathbf{1 0}} \mathbf{H}_{\mathbf{1 6}}\right)$ \\
\hline S. Korea & 0.20 & 0.07 \\
N. Korea & 0.18 & 0.06 \\
Japan & 0.57 & 0.31 \\
Taiwan & 0.15 & 0.05 \\
Mongolia & 0.28 & 0.09 \\
China & 9.99 & 3.74 \\
Laos & 1.91 & 0.50 \\
Thailand & 3.31 & 0.90 \\
Vietnam & 2.06 & 0.62 \\
Myanmar & 5.83 & 1.40 \\
India & 12.41 & 2.67 \\
Philippines & 3.25 & 0.47 \\
Bangladesh & 1.05 & 0.19 \\
Bhutan & 0.05 & 0.02 \\
Brunei & 0.23 & 0.03 \\
Cambodia & 2.15 & 0.51 \\
Indonesia & 33.15 & 5.86 \\
Malaysia & 7.63 & 1.20 \\
Nepal & 0.45 & 0.11 \\
Pakistan & 1.73 & 0.22 \\
Singapore & 0.01 & 0.00 \\
Sri Lanka & 0.56 & 0.12 \\
Total & 87.14 & 19.133 \\
\hline
\end{tabular}

The biogenic emissions distribution for each Asian regional are shown in Figure 11, which shows that, in contrast to anthropogenic emissions, S. E. Asia contributed the most, emitting from 41 to $68 \%$ of the Asian total, while E. Asia made the smallest contribution.

For isoprene $\left(\mathrm{C}_{5} \mathrm{H}_{8}\right)$, which accounts for the largest share of vegetation VOCs, the top emitters were Indonesia (33.1 Tg/yr), India (12.4 Tg/yr), China (10.0 Tg/yr), Myanmar (7.6 Tg/yr), and Malaysia ( $5.8 \mathrm{Tg} / \mathrm{yr})$, followed by the rest of Asia. These five countries accounted for $79 \%$ of the Asian biogenic isoprene emissions total.

The top emitters for monoterpene $\left(\mathrm{C}_{10} \mathrm{H}_{16}\right)$, which contributes significantly to secondary fine particulates production through photochemical reactions with isoprene $\left(\mathrm{C}_{5} \mathrm{H}_{8}\right)$, were Indonesia (5.9 Tg/yr), China (3.7 Tg/yr), India (2.7 Tg/yr), Myanmar (1.4 Tg/yr), and Malaysia (1.2 Tg/yr), with these five accounting for $77 \%$ of the Asian biogenic monoterpene emissions total (Figure 12).

As can be seen in Figure 13, biogenic emissions showed seasonal variations in response to the differing environmental conditions, such as temperature, solar radiation, and precipitation. Figure 14 indicates that isoprene emissions peaked in June, while monoterpenes peaked in July-August. Emissions of both isoprene and monoterpenes were approximately $65 \%$ higher in the hot season (April-September) than they were in the cold season (October-March), mainly because their causal factors (such as temperature, solar radiation intensity, and plant distribution density) also peak in summer. 


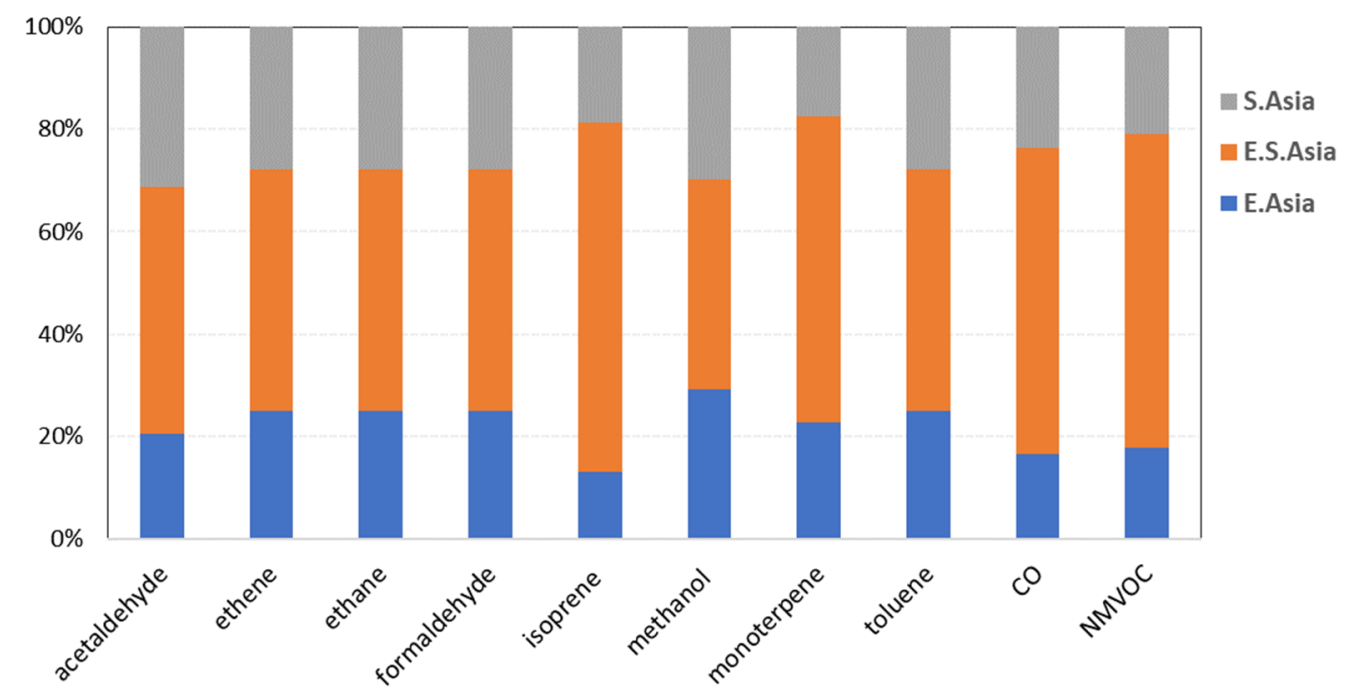

Figure 11. Biogenic emission contributions by Asian regional groups.
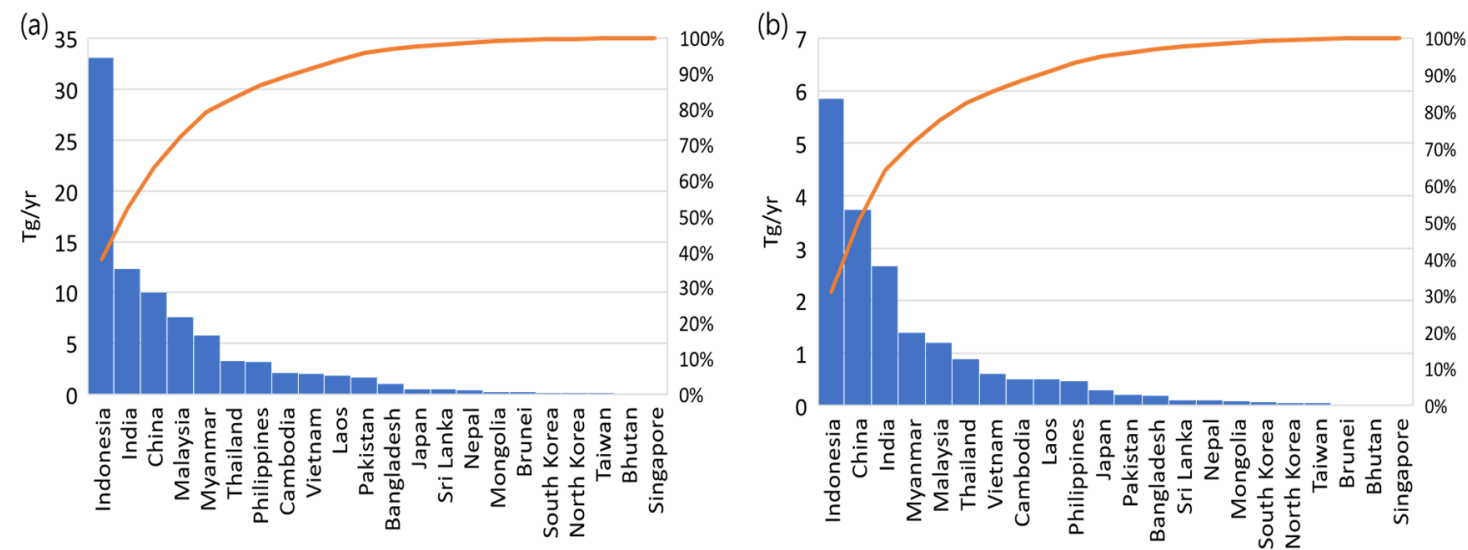

Figure 12. Asian distribution of annual biogenic (a) isoprene $\left(\mathrm{C}_{5} \mathrm{H}_{8}\right)$ and $(\mathbf{b})$ monoterpene $\left(\mathrm{C}_{10} \mathrm{H}_{16}\right)$ emissions (unit: $\mathrm{Tg} / \mathrm{yr}$ ).

As can be seen in Figure 13, biogenic emissions showed seasonal variations in response to the differing environmental conditions, such as temperature, solar radiation, and precipitation. Figure 14 indicates that isoprene emissions peaked in June, while monoterpenes peaked in July-August. Emissions of both isoprene and monoterpenes were approximately $65 \%$ higher in the hot season (April-September) than they were in the cold season (October-March), mainly because their causal factors (such as temperature, solar radiation intensity, and plant distribution density) also peak in summer. 


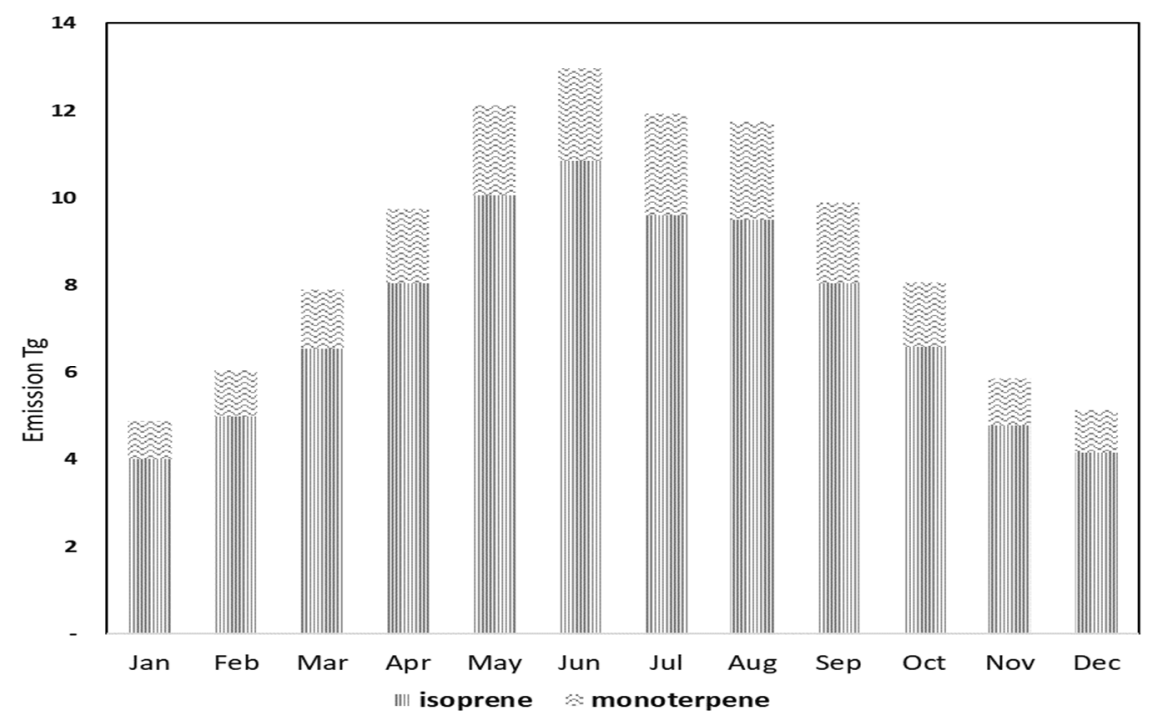

Figure 13. Monthly Asian biogenic isoprene and monoterpene emissions (Tg).

(a)

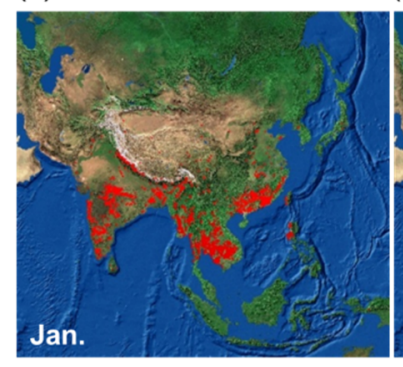

(b)

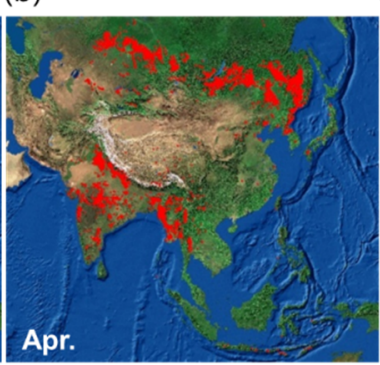

(c)

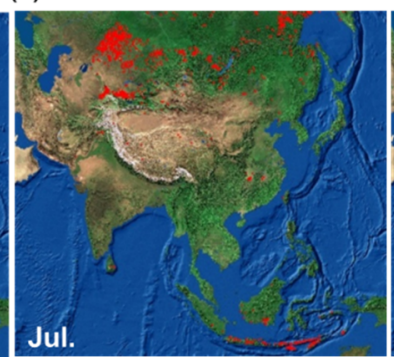

(d)

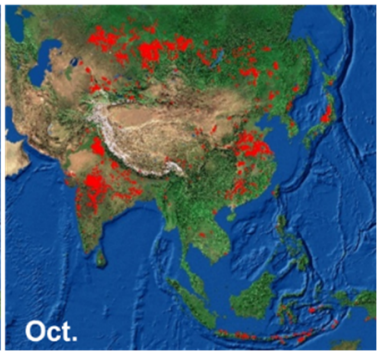

Figure 14. Seasonality in fire location spatial distribution estimates: (a) January, (b) April, (c) July and (d) October.

\subsubsection{Biomass Burning Emissions}

Location emissions estimated using MODIS burned-area data (MCD45A1), https://ladsweb. modaps.eosdis.nasa.gov/ [42]) are shown in Figure 14, where we have summarized January, April, July, and October data as representatives of the four seasons to help explain both the regional and seasonal nature of biomass burning event distribution.

In winter (as represented by Jan. in Figure 15), fewer fire events or burned areas were seen than in spring (April), with those that did occur located south of $25^{\circ} \mathrm{N}$, in S. Asia, S. E. Asia, and southern China, and none seen above $30^{\circ} \mathrm{N}$.

Compared with other seasons, in spring numerous fire events were apparent, not only in Asia but also in southern Siberia, while in summer (July), the fewest biomass burning events and the smallest biomass burning area occurred. Comparing spring with summer (April and July), the burned areas were much larger in April than they were for July, while for fall (October), the burned area was again observed to be rather high for S. E. Asia. This burned area seasonality generally aligned well with previously published findings [43].

Figure 15 shows that the area burned in spring accounted for $60 \%$ of the total. In Asia, the lowest total combustion area occurred in summer (June-August), most likely due to the influence of monsoon cloud formation and significant rainfall. Overall, the largest burned area was seen in spring, peaking in May in E. Asia, and February in S. E. Asia. In S. Asia, significant areas of burning were observed, compared with the other two Asian regions, especially in May. Given that the most populous areas are found in the mid-latitudes, direct human health impacts from biomass burning are likely to be the highest there. In Siberia and Kazakhstan, burned areas regularly appear in summer, 
contrary to more southern Asian locations, with large and intense burning detected over April and May, concentrated mostly in the Siberian region.

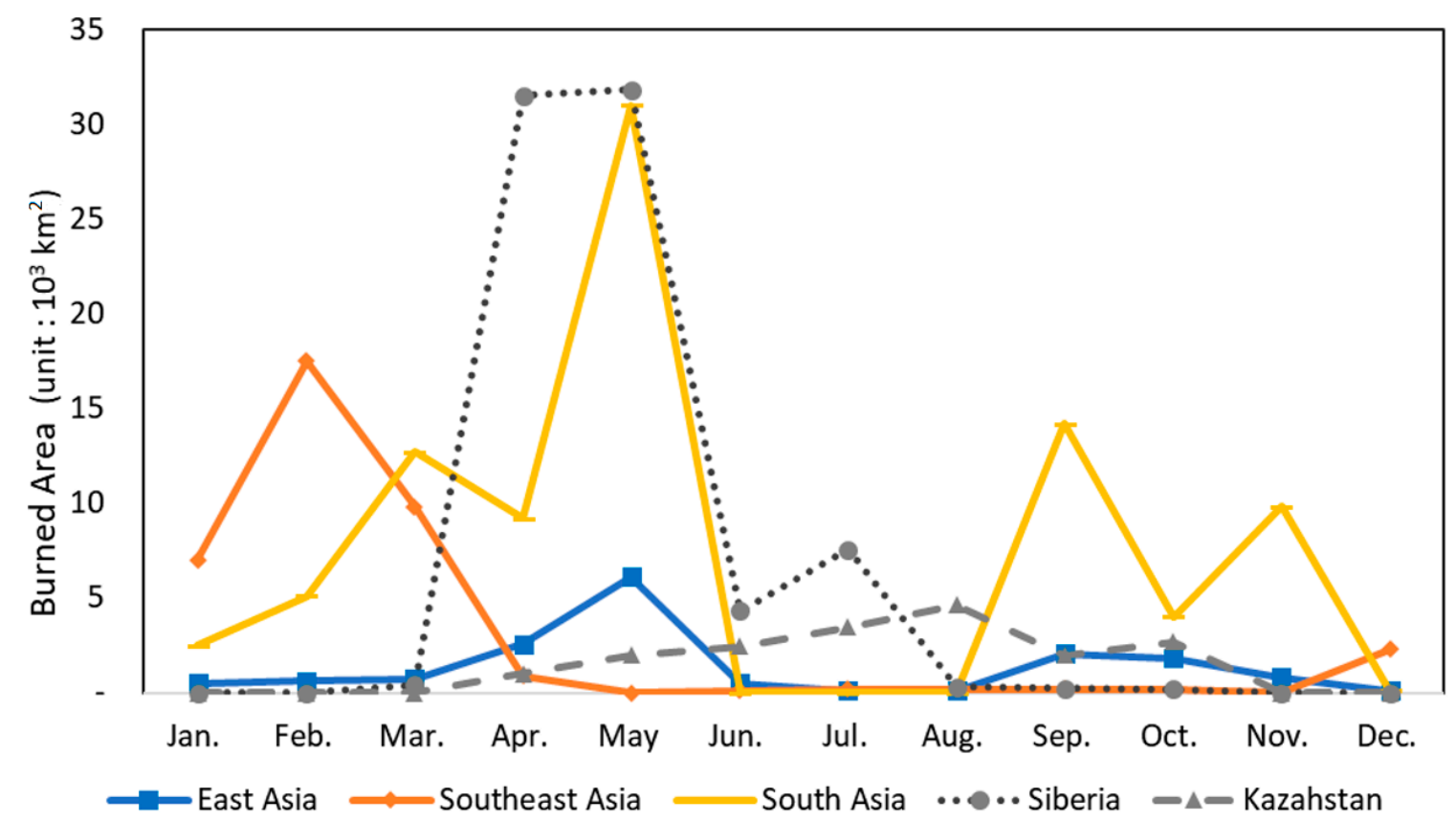

Figure 15. Monthly burned area variation, by region.

$2009 \mathrm{CO}, \mathrm{PM}_{2.5}$, and nonmethane hydrocarbons (NMHC) emissions from biomass burning are summarized in Table 6, by subregion, total annual Asian emissions, and by emissions totals for all Asian regions.

Total 2009 Asian CO emissions from biomass burning were $37.6 \mathrm{Tg}$, with S. Asia contributing $61 \%$ (23 Tg), S. E. Asia 28\% (10.4 Tg), and E. Asia 11\% (4.1 Tg). Total Asia emissions accounted for $59 \%$ of the study area, with S. Asia being the largest contributor, not only in Asia but across the whole domain. Siberia made the second highest contribution, followed by S. Asia, which accounted for $>30 \%$ of the whole domain. E. Asia made the smallest contribution at $5-7 \%$ of the whole domain (Table 7). As illustrated in Figure 16, these results correlated strongly with the burned areas and fire event numbers.

Monthly sub-regional CO emissions from biomass burning are shown in Figure 17, which shows that in the target year these emissions were concentrated between February and May in Asia, while becoming significantly reduced in June and August, due to weather conditions such as rainfall and humidity. In the fall, from September to November, biomass burning emissions increased again, although at a lower level than in spring. Overall, the highest emissions occurred in May, presumably from S. Asian locations such as India, while Siberia and S. Asia contributed approximately $49 \%$ and $44 \%$, respectively. In April, $75 \%$ of the emissions appeared from the Siberian region, and in Asia, as in May, the highest contribution came from S. Asia, at 20\%, which was lower than May. From January-March, Siberian contributions were rare, with most emissions occurring in Asia. Overall, these monthly emission variations showed patterns very similar to those seen for both the areas burned and fire event numbers.

Table 7. Summary of emissions from biomass burning for the year 2009 (Tg/year).

\begin{tabular}{ccccccc}
\hline & East Asia & Southeast Asia & South Asia & Siberia & Kazakhstan & Total \\
\hline $\mathrm{PM}_{2.5}$ & 0.5 & 1.2 & 2.7 & 2.4 & 0.6 & 7.3 \\
$\mathrm{CO}$ & 4.1 & 10.4 & 23.0 & 22.8 & 4.7 & 65.0 \\
$\mathrm{NMHC}$ & 0.1 & 0.3 & 0.8 & 0.7 & 0.2 & 2.2 \\
\hline
\end{tabular}




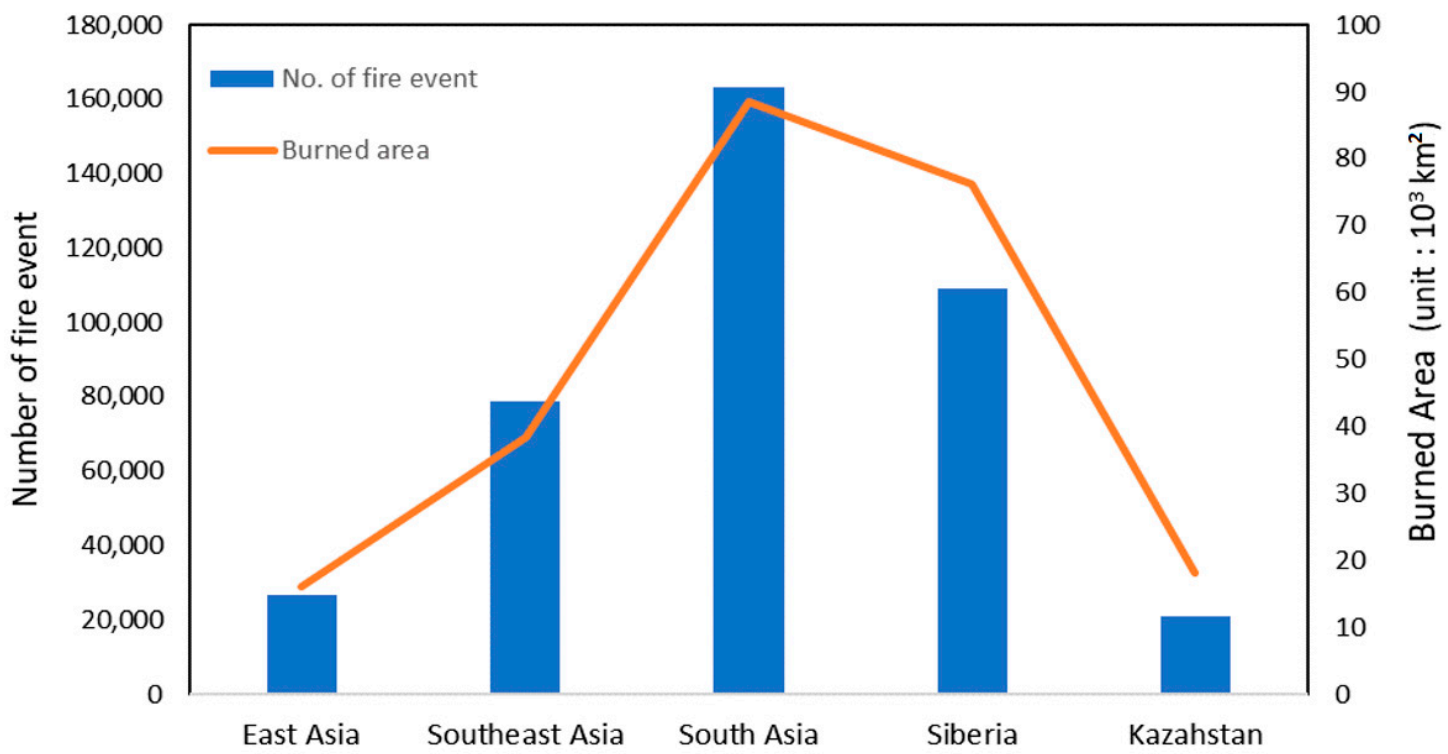

Figure 16. Sub-regional fire event numbers (blue bars) and total burned areas (red line).

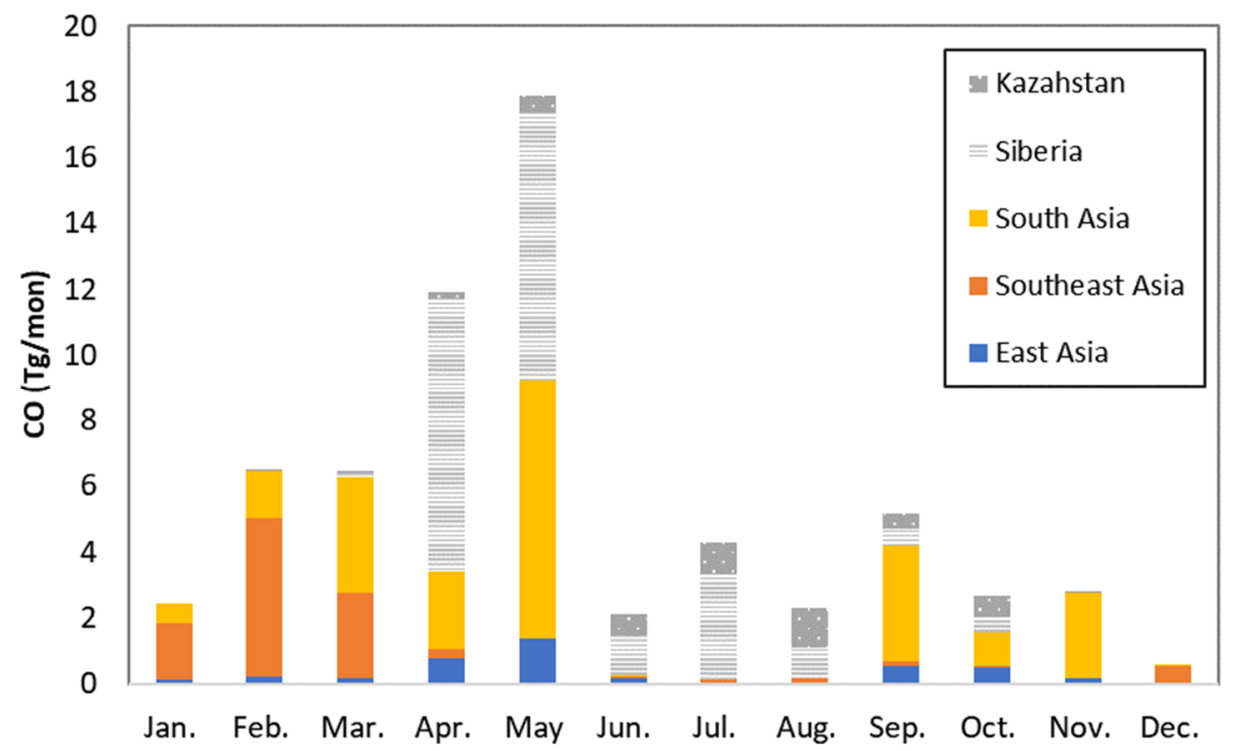

Figure 17. Monthly $\mathrm{CO}$ emissions from biomass burning, showing selected regional contributions.

\subsection{Comparisons between This Study and Other Emissions Datasets}

To better understand differences among anthropogenic emission estimates, we reviewed total emissions estimate differences for Asia, calculated for the same base year as this study. To do this, we compared the CREATE inventory outcomes with those produced by the REAS v3.1 (Regional Emissions Inventory in ASia v3.1) [44], MICS (the Model Inter-Comparison Study for Asia) [45], ECLIPSE v5a [46], and EDGAR v4.3.2 [47] inventories (Figure 18). We found that the all-Asia CO, $\mathrm{SO}_{2}$, and $\mathrm{NH}_{3}$ emissions estimates from CREATE showed a range similar to those of the other inventories, although $\mathrm{NO}_{\mathrm{x}}$ and VOC estimates averaged $26 \%$ and $21 \%$ lower, respectively, and the CREATE $\mathrm{PM}_{2.5}$ estimates were $17 \%$ higher. The largest difference in the emissions ranges, of $80-139 \%$ across the various pollutants, was found between the CREATE and MICS inventories. We found that the ECLIPSE model produced values that were the closest to CREATE; this was not unexpected, as both inventories were based on the GAINS model, had the same source categories and used the same emissions factors, with the exceptions of China, N. Korea, and S. Korea. 


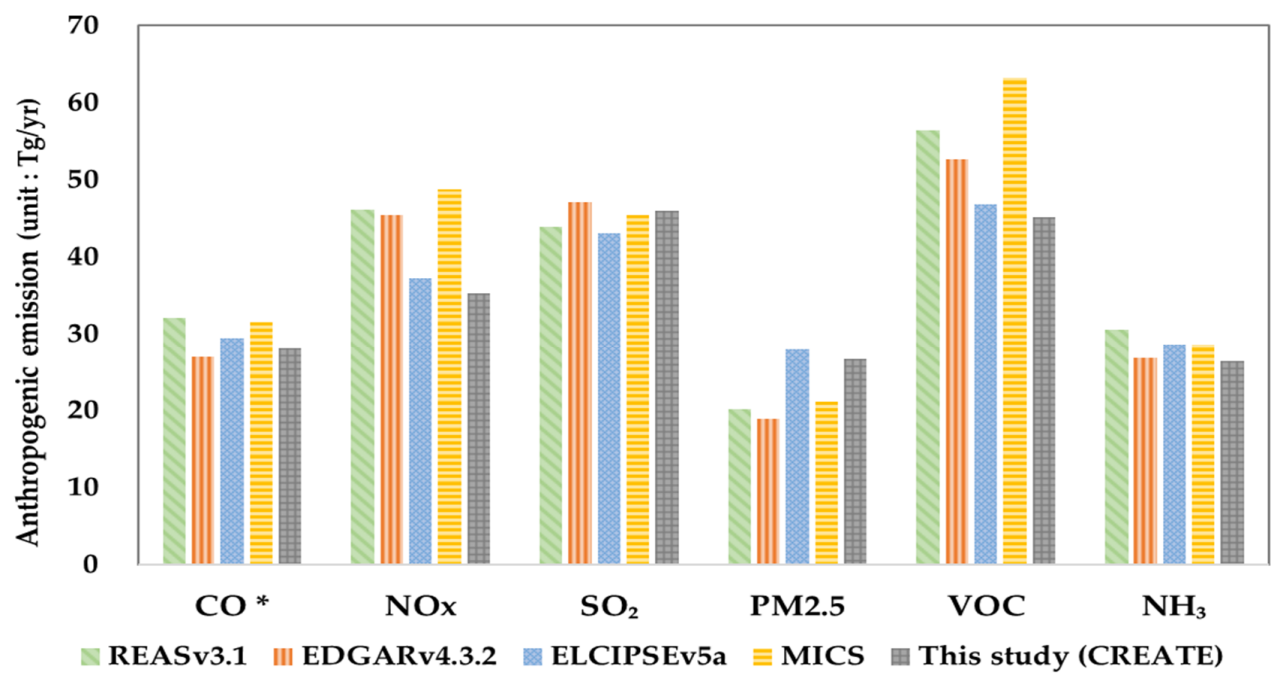

Figure 18. Asian anthropogenic emissions comparisons using estimates calculated from different inventories (unit: $\mathrm{Tg} / \mathrm{yr} ;{ }^{*}$ indicates that $\mathrm{CO}$ values have been divided by 10 ).

In Figure 19, we can see a comparison between CREATE inventory emissions for China with those from previous studies, with CREATE represented by the black bar with a check pattern and other inventories indicated by variously marked dots. The figure shows that for $\mathrm{CO}$, the CREATE results were $1-14 \%$ lower than those from the other inventories, apart from EDGAR, whose CO emission estimate were much lower (37-45\%) than those from the other studies. $\mathrm{For}_{2} \mathrm{SO}_{2}$, the CREATE estimate was high, at $29.85 \mathrm{Tg}$, which was $4-17 \%$ above estimates from the other inventories, apart from that from Lu et al. [48], which was 3\% lower.

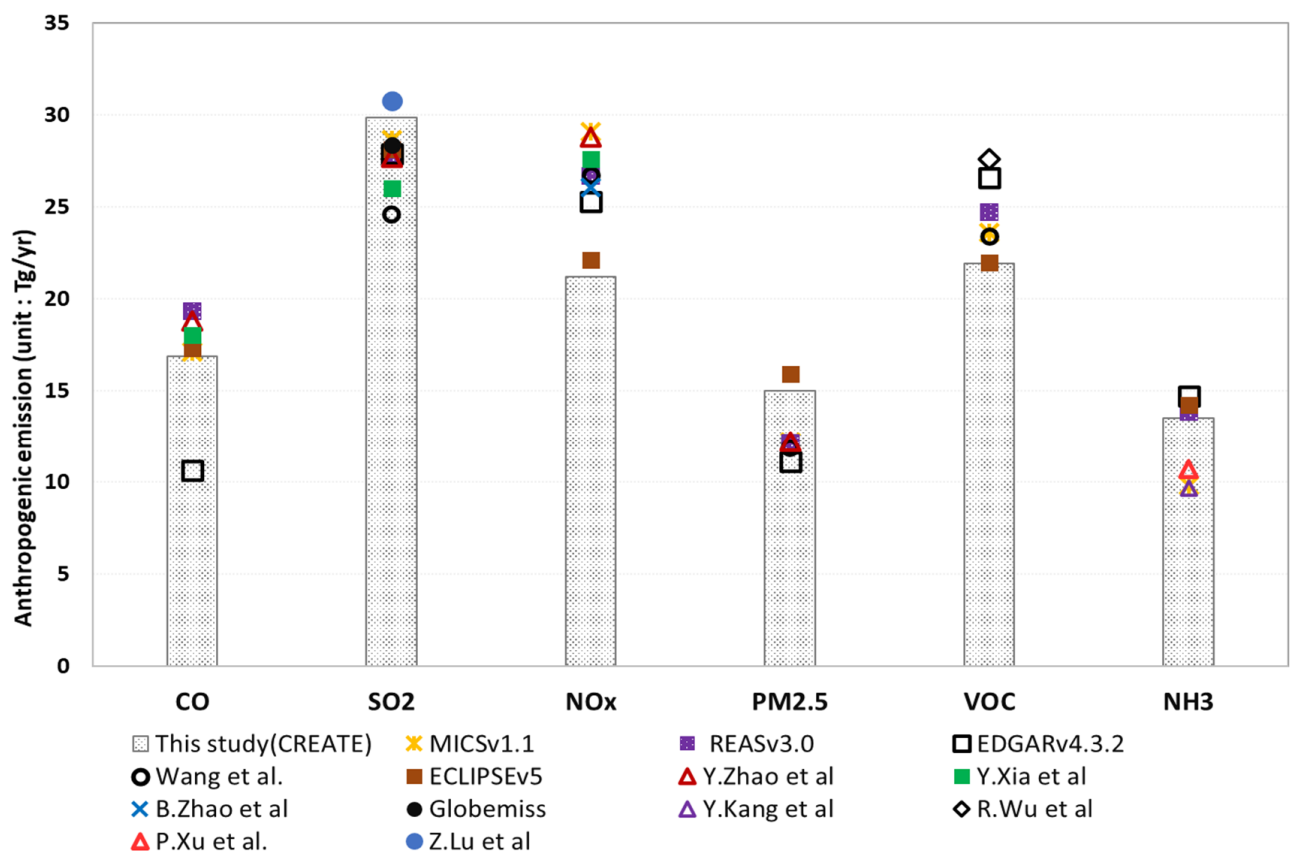

Figure 19. Comparing Chinese 2010 anthropogenic emission estimates using various emission inventories (unit: $\mathrm{Tg} / \mathrm{yr}$; ${ }^{*}$ indicates that CO values have been divided by 10). (source: MICS [45], REAS [44], EDGAR [47], Wang et al. [51], ECLIPSE [46], Y.Zhao et al. [52], Y.Xia et al. [53], B.Zhao et al. [14], Globemiss [54], Y.Kang et al. [49], R.Wu et al. [55], P.Xu et al. [50], Z.Lu et al. [48])).

We found that CREATE $\mathrm{NO}_{\mathrm{x}}$ emission estimates were $11-37 \%$ lower than those from the other inventories, exhibiting the lowest values. There were greater differences between the various 
inventories for $\mathrm{NO}_{\mathrm{x}}, \mathrm{VOC}$, and $\mathrm{NH}_{3}$ than there were for the other emission species, while the MICS $\mathrm{CO}$ and $\mathrm{SO}_{2}$ emissions estimates showed good agreement (within 3\%) with those from CREATE, although large differences were apparent between the two inventories with respect to their $\mathrm{NO}_{\mathrm{x}}$ and VOC emissions estimates. These latter differences may be showing how local $\mathrm{NO}_{\mathrm{x}}$ and VOC studies captured Chinese domestic information that was more accurate and were thus better able to reflect increases in car use, industrial source emissions, and solvent usage there.

We found that the ECLIPSE VOC emission estimate was in very good agreement with that of CREATE (within 0.3\%), with all other emissions estimates also in good agreement (within 5\%). Compared with inventories other than ECLIPSE, the CREATE $\mathrm{PM}_{2.5}$ emission estimate was much higher. While for $\mathrm{NH}_{3}$, two distinct groups were apparent, with REAS, ECLIPSE, and EDGAR showing relatively good agreement with CREATE (all $<8 \%$ difference), and MICS, Kang et al. [49], and Xu et al. [50], showing much larger differences (all $>21 \%$ difference). There were also differences of $>30 \%$ between these two groups.

A comparison between the biogenic emission estimates calculated in this study with previously published estimates is presented in Table 7. The annual Asia isoprene estimate from CREATE was 87.1 $\mathrm{Tg}$, which was between $-4 \%$ and $39 \%$ of the other studies. The CREATE isoprene emission estimate was closest to those published in Stavrakou et al. (2014), and the differences for China were smaller (within $8 \%$ ) than they were for the rest of Asia. The main reason for the larger differences might be either the use of different model frameworks or different MEGAN versions for emission calculations. Vegetation information (such as vegetation cover and leaf area), meteorological data, and EFs make up the input parameters for biogenic emission modeling, and the specific algorithms for BVOC compound species relate their emissions to surrounding weather conditions. This suggests that there might be differences in EFs and estimation algorithms between each model. We also noted that different target years were used, suggesting that input weather conditions and vegetation information may have differed, which could give rise to emissions discrepancies. Wang et al. [56] reported that meteorological conditions, particularly temperature and solar radiation, could affect isoprene estimates by up to $27 \%$ and $51 \%$, respectively.

For monoterpenes, our emission estimates were approximately $18 \%$ and $23 \%$ higher for Asia and China, respectively, compared with the other inventories, although the China monoterpene emission estimate in Klinger et al. (2002) was in very good agreement (within $0.1 \%$ ) with that achieved using CREATE (Table 8).

Table 8. Inter-comparison of biogenic emissions for China and Asia with other studies [unit: Tg/yr].

\begin{tabular}{cccccc}
\hline Isoprene [Tg/yr] & Asia & China & Monoterpene [Tg/yr] & Asia & China \\
\hline Guenther et al. (2012) [29] & 62.7 & 9.3 & Guenther et al. (2012) [29] & 16.2 & 2.8 \\
Guenther et al. (2006) [28] & 81.7 & 10.9 & Y. Fu et al. (2012) [57] & & 3.0 \\
T. Stavrakou et al. (2014) [58] & 90.4 & 9.3 & Klinger et al (2002) [59] & & 3.7 \\
Y. Fu et al. (2012) [57] & & 10.9 & This study (CREATE) & 19.1 & 3.7 \\
This study (CREATE) & 87.1 & 10.0 & & & \\
\hline
\end{tabular}

An inter-comparison between biomass burning emission estimates from this study with those from the Global Fire Emissions Database, Version 4 (GFEDv4) inventory [60,61] and Kaiser et al. [62] was used. The GFEDv4 estimates consist of an average for 2000-2009, while those from Kaiser et al. cover the period 2003-2008. The estimates from this study were higher than those from GFEDv4 and lower than those in Kaiser et al., with the CO emission estimates being 5\% higher than those in GFEDv4, and $9 \%$ lower than those in Kaiser et al. For $\mathrm{PM}_{2.5}$, our emission estimates were approximately $10 \%$ and 3\% higher compared with GFEDv4 and Kaiser et al., respectively. Our result agreed within $\pm 10 \%$, compared to other inventories. 


\subsection{Uncertainties and Limitations}

The emissions used to derive bottom-up anthropogenic inventory estimates were assembled from a variety of human statistics data sources. Generally, such documentation is published with a time lag of several years, while the pace of change in many Asian countries has been increasing, leading to rapid economic development and increasing efforts at mitigating air/climate pollutant emissions. These rapid emission changes make it difficult to maintain emission input statistic currency and to reflect the rapid changes happening in Asia-which in turn leads inevitably to a degree of uncertainty in the representativeness of data. In addition, some countries-such as N. Korea-publish very limited amounts of data, so that, overall, data reliability constitutes a source of uncertainty and limitation for this study.

Biogenic emission estimation is highly dependent on vegetation-related parameters and weather conditions. As mentioned in Section 3.3, using different modeling frameworks or versions (of MEGAN, for example) can cause discrepancies in emission calculations. Henrot et al. [63] also noted that most discrepancies between model calculations could be attributed to meteorological parameter inputs and to LAI and PFT distributions, which can be the source of major uncertainties. This implies that input parameters need to be subjected to appropriate sensitivity testing and should be sampled over longer time periods where possible to support more accurate estimate calculations. Rapid economic development and urbanization throughout Asia continue to cause landcover and land use changes, which also add to emission estimate accuracy uncertainty.

Biomass burning emission estimates can be strongly affected by both fire observation information and burned area size estimates. This means that natural source emissions, from both biogenic sources and biomass burning, include uncertainties related to both meteorological variables and to remote-sensing data uncertainty. Satellite observations are sometimes affected by cloud contamination, for example, as described in Streets et al. [43].

Anthropogenic emissions inventory was estimated based on annual energy statistics, policy measures, and emissions factors whereas natural emissions were estimated using comprehensive emission models with a much more diverse set of input data. Some of the input parameters of the natural emission models were not available for the same period as the anthropogenic emission input data. The base year of natural emissions is a year older than anthropogenic because of the data limitation during the development period. We will use the same base year for every emission source in our new development of the inventory.

These issues will form part of our future research focus, which will aim to update and improve the work described here. We need to continue our evaluation experiments by including more ambient data observations, and by updating and improving CREATE emission data, in order to build on the outcomes achieved so far in this study.

\subsection{Data Availability}

We have launched a data download platform for the CREATE inventory at http://aisl.konkuk.ac.kr/ \#/emission_data/create_emission_inventory. Monthly gridded emission data sets for each major sector, at $0.1^{\circ} \times 0.1^{\circ}$ resolution for Asia, and $3 \times 3 \mathrm{~km}$ resolution for $\mathrm{S}$. Korea, can be downloaded for all species. Data provenance information and a summary table of annual emissions by sector can also be accessed.

\section{Summary and Conclusions}

We developed a new regional emissions inventory, named CREATE (Comprehensive Regional Emissions Inventory for Atmospheric Transport Experiment). This was designed as a comprehensive emissions framework, including both anthropogenic, biogenic, and biomass burning emissions estimates. Since the emissions in CREATE were estimated based on human and natural activities, both static databases and dynamic models had to be broadly applied in the framework, and then integrated into the final inventory database. The target species in this 
work included major air pollutants and GHGs, with estimates calculated for both national and regional emissions.

Anthropogenic emissions were developed using the GAINS-Asia framework, which is an integrated policy assessment model. Major activity data were sourced from official national or international statistics to estimate anthropogenic emission totals in CREATE, while EFs and data on the degree of control equipment penetration (such as FGD and SCR) were updated using published literature and government reports.

Our final estimates for Asian total anthropogenic emissions in 2010 were as follows: $\mathrm{CH}_{4}-109.4 \mathrm{Tg}$; $\mathrm{CO}-280.5 \mathrm{Tg} ; \mathrm{CO}_{2}-14.1 \mathrm{Pg} ; \mathrm{N}_{2} \mathrm{O}-4.1 \mathrm{Tg} ; \mathrm{NH}_{3}-26.4 \mathrm{Tg} ; \mathrm{NO}_{\mathrm{x}}-35.3 \mathrm{Tg} ; \mathrm{PM}_{10}-37.4 \mathrm{Tg}$; $\mathrm{PM}_{2.5}-26.7 \mathrm{Tg} ; \mathrm{SO}_{2}-46.0 \mathrm{Tg}$; and VOCs-45.2 Tg.

Estimates for nine biogenic emissions in 2009 were calculated, using the MEGAN modeling framework. The model estimates for isoprene emissions in Asia were $87.1 \mathrm{Tg} / \mathrm{yr}$, with $19.3 \mathrm{Tg} / \mathrm{yr}$ estimated for monoterpenes. Indonesia, China, and India together accounted for $64 \%$ of Asian biogenic emissions.

Biomass-burning emissions in the CREATE inventory were calculated for 2009 using the BlueSky model. We adapted this model for Asia, developing a BlueSky-Asia modeling system, combining this with SMOKE-Asia [7], which is an emission processing system. Modeling outputs were generated as speciated, three-dimensional, model-ready input data for AQ modeling. Total Asia CO emissions from biomass burning were estimated to be $37.6 \mathrm{Tg}$ in 2009 ; S. Asia contributed $61 \%$ (23 Tg) of this total, S. E. Asia $28 \%(10.4 \mathrm{Tg})$, and E. Asia $11 \%$ (4.1 Tg). We found that the results were strongly influenced by the amount of area burned and by the number of fire events.

CREATE emissions estimates were established for anthropogenic, biogenic, and biomass burning emissions using the same domain, resolution, and period. Final inventory estimates were based on activities and other parameters, which formed fundamental information for the resulting emissions. These characteristics allow CREATE emissions to be applied to many research areas, such as future emission projections, policy-based reduction scenarios, and CC-driven emissions changes. Since SMOKE-Asia, MEGAN, and BlueSky-Asia are either members or linked components of the CREATE inventory framework, its format could be easily adapted to chemical transport modeling. It also can be useful for N. E. Asian studies, as its base year (2010) was an important turning point in emissions reduction, as noted in Woo et al. [64] and Zheng et al. [65].

We believe that our work successfully fulfilled our objective, which was to develop an inventory scheme that provides better support for AQ modeling and which can be operated in concert with the SMOKE-Asia emissions processing system. We hope that the CREATE emissions inventory presented in this paper will contribute to a better understanding of regional air pollution and its influence on human health and climate. We also hope it will provide a basis for future environmental policies and will contribute to international cooperation in the field of regional policy analysis and support. We plan to continue updating and improving the CREATE inventory framework developed in this study.

Author Contributions: Conceptualization, J.-H.W. and Y.K.; methodology, J.-H.W., Y.K., H.-K.K. and K.-C.C.; data production and analysis, Y.K., H.-K.K., K.-C.C. and J.-H.E.; writing- original draft preparation, J.-H.W. and Y.K.; writing-review and editing, J.-H.W., Y.K. and J.-H.E.; supervision, J.-H.W., J.-B.L. and J.-H.L.; project management and coordination, J.-B.L., J.-H.L. J.K. and M.S.; funding acquisition, J.-B.L. and J.-H.L. All authors have read and agreed to the published version of the manuscript.

Funding: This research was supported by the Korea Environment Industry \& Technology Institute (KEITI), through its Public Technology Program, based on Environmental Policy Program, funded by Korea Ministry of Environment (grant number: 2019000160007); and by a grant from the National Institute of Environmental Research (NIER), funded by the Ministry of Environment (MOE) of the Republic of Korea (ex: NIER 2019-01-02-037).

Conflicts of Interest: The authors declare no conflict of interest. 


\section{References}

1. Ohara, T.; Akimoto, H.; Kurokawa, J.; Horii, N.; Yamaji, K.; Yan, X.; Hayasaka, T. An Asian emission inventory of anthropogenic emission sources for the period 1980-2020. Atmos. Chem. Phys. 2007, 7, 4419-4444. [CrossRef]

2. Kurokawa, J.; Ohara, T.; Morikawa, T.; Hanayama, S.; Janssens-Maenhout, G.; Fukui, T.; Kawashima, K.; Akimoto, H. Emissions of air pollutants and greenhouse gases over Asian regions during 2000-2008: Regional Emission inventory in ASia (REAS) version 2. Atmos. Chem. Phys. 2013, 13, 11019-11058. [CrossRef]

3. Jang, Y.; Lee, Y.; Kim, J.; Kim, Y.; Woo, J.-H. Improvement China Point Source for Improving Bottom-Up Emission Inventory. Asia Pac. J. Atmos. Sci. 2019, 56, 107-118. [CrossRef]

4. Streets, D.G.; Bond, T.C.; Carmichael, G.R.; Fernandes, S.D.; Fu, Q.; He, D.; Klimont, Z.; Nelson, S.M.; Tsai, N.Y.; Wang, M.Q. An inventory of gaseous and primary aerosol emissions in Asia in the year 2000. J. Geophys. Res. Atmos. 2003, 108. [CrossRef]

5. Zhang, Q.; Streets, D.G.; Carmichael, G.R.; He, K.B.; Huo, H.; Kannari, A.; Klimont, Z.; Park, I.S.; Reddy, S.; $\mathrm{Fu}$, J.S.; et al. Asian emissions in 2006 for the NASA INTEX-B mission. Atmos. Chem. Phys. 2009, 9, 5131-5153. [CrossRef]

6. Olivier, J.G.J.; Van Aardenne, J.A.; Dentener, F.J.; Pagliari, V.; Ganzeveld, L.N.; Peters, J.A.H.W. Recent trends in global greenhouse gas emissions: Regional trends 1970-2000 and spatial distributionof key sources in 2000. Environ. Sci. 2005, 2, 81-99. [CrossRef]

7. Woo, J.-H.; Choi, K.-C.; Kim, H.K.; Baek, B.H.; Jang, M.; Eum, J.-H.; Song, C.H.; Ma, Y.-I.; Sunwoo, Y.; Chang, L.-S.; et al. Development of an anthropogenic emissions processing system for Asia using SMOKE. Atmos. Environ. 2012, 58, 5-13. [CrossRef]

8. Amann, M.; Bertok, I.; Borken, J.; Chambers, A.; Cofala, J.; Dentener, F.; Heyes, C.; Hoglund, L.; Klimont, Z.; Purohit, P.; et al. A tool to combat air pollution and climate change simultaneously. In GAINS-Asia Methodology Report; IIASA: Laxenburg, Austria, 2008.

9. World Energy Statistics. Available online: https://www.iea.org/subscribe-to-data-services/world-energybalances-and-statistics (accessed on 31 July 2020).

10. China Industry Research Reports Data. Available online: http://www.chinairr.org/ (accessed on 24 July 2020).

11. National Air Pollutants Emission Service. Available online: http://airemiss.nier.go.kr/mbshome/mbs/airemiss/ index.do (accessed on 2 April 2020).

12. Statistics Bureau of Japan. Available online: http://www.stat.go.jp/english/data/nenkan/index.html (accessed on 31 March 2020).

13. United Nations Statistics. Available online: https://unstats.un.org/unsd/energystats/data/ (accessed on 8 January 2020).

14. Zhao, B.; Wang, S.; Liu, H.; Xu, J.Y.; Fu, K.; Klimont, Z.; Hao, J.M.; He, K.B.; Cofala, J.; Amann, M. NOx emissions in China: Historical trends and future perspectives. Atmos. Chem. Phys. 2013, 13, 9869-9897. [CrossRef]

15. Huo, H.; Yao, Z.; Zhang, Y.; Shen, X.; Zhang, Q.; He, K. On-board measurements of emissions from diesel trucks in five cities in China. Atmos. Environ. 2012, 54, 159-167. [CrossRef]

16. Zhao, Y.; Wang, A.S.; Chris, P.; Nielsen, B.; Li, X.A.; Hao, J. Establishment of a database of emission factors for atmospheric pollutants from Chinese coal-fired power plants. Atmos. Environ. 2010, 44, 1515-1523.

17. Lei, Y.; Zhang, Q.; Nielsen, C.; He, K. An inventory of primary air pollutants and $\mathrm{CO}_{2}$ emissions from cement production in China, 1990-2020. Atmos. Environ. 2011, 45, 147-154. [CrossRef]

18. Zhao, Y.; Chris, P.; Nielsen, M.; McElroy, B.; Zhang, L.; Zhang, J. CO emissions in China: Uncertainties and implications of improved energy efficiency and emission control. Atmos. Environ. 2012, 49, 103-113. [CrossRef]

19. GAINS-Online. Available online: http://gains.iiasa.ac.at/index.php/home-page/241-on-line-access-to-gains (accessed on 31 August 2020).

20. Kota, S.H.; Schade, G.; Estes, M.; Boyer, D.; Ying, Q. Evaluation of MEGAN predicted biogenic isoprene emissions at urban locations in Southeast Texas. Atmos. Environ. 2015, 110, 54-64. [CrossRef]

21. Kim, H.-K.; Song, C.-K.; Han, K.M.; Eo, Y.D.; Song, C.H.; Park, R.; Hong, S.-C.; Kim, S.-K.; Woo, J.-H. Impact of biogenic emissions on early summer ozone and fine particulate matter exposure in the Seoul Metropolitan Area of Korea. Air Qual. Atmos. Health 2018, 11, 1021-1035. [CrossRef] 
22. Wu, K.; Yang, X.-Y.; Chen, D.; Gu, S.; Lu, Y.; Jiang, Q.; Wang, K.; Ou, Y.; Qian, Y.; Shao, P.; et al. Estimation of biogenic VOC emissions and their corresponding impact on ozone and secondary organic aerosol formation in China. Atmos. Res. 2020, 231, 104656. [CrossRef]

23. Guenther, A.; Hewitt, C.N.; Erickson, D.; Fall, R.; Geron, C.; Graedel, T.; Harley, P.; Klinger, L.; Lerdau, M.; McKay, W.A.; et al. A global model of natural volatile organic compound emissions. J. Geophys. Res. Atmos. 1995, 100, 8873-8892. [CrossRef]

24. Christensen, J.H.B.; Hewitson, A.; Busuioc, A.; Chen, X.; Gao, I.; Held, R.; Jones, R.K.; Kolli, W.-T.; Kwon, R.; Laprise, V.; et al. Regional Climate Projections. In Climate Change 2007: The Physical Science Basis. Contribution of Working Group I to the Fourth Assessment Report of the Intergovernmental Panel on Climate Change; Solomon, S.D., Qin, M., Manning, Z., Chen, M., Marquis, K.B., Averyt, M., Tignor, H.L.M., Eds.; Cambridge University Press: New York, NY, USA, 2007.

25. Limbeck, A.; Kulmala, M.; Puxbaum, H. Secondary organic aerosol formation in the atmosphere via heterogeneous reaction of gaseous isoprene on acidic particles. Geophys. Res. Lett. 2003, 30. [CrossRef]

26. Carlton, A.G.; Wiedinmyer, C.; Kroll, J.H. A review of Secondary Organic Aerosol (SOA) formation from isoprene. Atmos. Chem. Phys. 2009, 9, e4987-e5005.

27. Pacifico, F.; Harrison, S.P.; Jones, C.; Sitch, S. Isoprene emissions and climate. Atmos. Environ. 2009, 43, 6121-6135. [CrossRef]

28. Guenther, A.; Karl, T.; Harley, P.; Wiedinmyer, C.; Palmer, P.I.; Geron, C. Estimates of global terrestrial isoprene emissions using MEGAN (Model of Emissions of Gases and Aerosols from Nature). Atmos. Chem. Phys. 2006, 6, 3181-3210.

29. Guenther, A.; Jiang, X.; Heald, C.L.; Sakulyanontvittaya, T.; Duhl, T.; Emmons, L.K.; Wang, X. The Model of Emissions of Gases and Aerosols from Nature version 2.1 (MEGAN2.1): An extended and updated framework for modeling biogenic emissions. Geosci. Model Dev. 2012, 5, 1471-1492.

30. Kim, H.-K.; Woo, J.-H.; Park, R.S.; Song, C.H.; Kim, J.-H.; Ban, S.-J.; Park, J.-H. Impacts of different plant functional types on ambient ozone predictions in the Seoul Metropolitan Areas (SMAs), Korea. Atmos. Chem. Phys. 2014, 14, 7461-7484.

31. Yarwood, G.; Rao, S.; Yocke, M.; Whitten, G.Z. Updates to the Carbon Bond chemical mechanism: CB05. In Final Report to the US EPA, RT-0400675; Yocke and Company: Novato, CA, USA, 2005.

32. Carter, W.P.L. Implementation of the SAPRC-99 chemical mechanism into the models-3 framework. In Report to the United States Environmental Protection Agency; EPA: Washington, DC, USA, 2000.

33. WRF Model Users' Page. Available online: http://www2.mmm.ucar.edu/wrf/users/ (accessed on 20 March 2018).

34. Pryden, A.D. Getting Started with the BlueSky Framework Version 3.0. Available online: https://citeseerx.ist. psu.edu/viewdoc/download?doi=10.1.1.528.303\&rep=rep1\&type=pdf (accessed on 30 July 2020).

35. Choi, K.-C.; Woo, J.-H.; Kim, H.-K.; Choi, J.; Eum, J.-H.; Baek, B.H. Modeling of Emissions from Open Biomass Burning in Asia Using the BlueSky Framework. Asian J. Atmos. Environ. 2013, 7, 25-37. [CrossRef]

36. Roy, D.P.; Jin, Y.; Lewis, P.; Justice, C. Prototyping a global algorithm for systematic fire-affected area mapping using MODIS time series data. Remote Sens. Environ. 2005, 97, 137-162. [CrossRef]

37. Roy, D.P.; Lewis, P.; Justice, C. Burned area mapping using multi-temporal moderate spatial resolution data-a bi-directional reflectance model-based expectation approach. Remote Sens. Environ. 2002, 83, 263-286. [CrossRef]

38. Roy, D.P.; Boschetti, L.; Justice, C.O.; Ju, J. The Collection 5 MODIS Burned Area Product-Global Evaluation by Comparison with the MODIS Active Fire Product. Remote Sens. Environ. 2008, 112, 3690-3707. [CrossRef]

39. National Institute of Environmental Research (NIER). 2011: National Air Pollutants Emission; NIER: Incheon, Korea, 2009.

40. Posada, F.; Kamakate, F.; Bandivadekar, A. Sustainable Management of Two and Three-Wheelers in Asia; ICCT Working Paper 2011-13; ICCT: Berlin, Germany, 2011.

41. The World Bank Open Data. Choice Rev. Online 2010, 48, 48.

42. NASA Earth Science Data. Available online: https://ladsweb.modaps.eosdis.nasa.gov (accessed on 2 March 2016).

43. Streets, D.G.; Yarber, K.F.; Woo, J.-H.; Carmichael, G.R. Biomass burning in Asia: Annual and seasonal estimates and atmospheric emissions. Glob. Biogeochem. Cycles 2003, 17. [CrossRef] 
44. Kurokawa, J.-I.; Ohara, T. Long-term historical trends in air pollutant emissions in Asia: Regional Emission inventory in Asia (REAS) version 3.1. Chem. Phys. Discuss 2019, 1-51. [CrossRef]

45. Li, M.; Zhang, Y.; Kurokawa, J.-I.; Woo, J.-H.; He, K.; Lu, Z.; Ohara, T.; Song, Y.; Streets, D.G.; Carmichael, G.R.; et al. MIX: A mosaic Asian anthropogenic emission inventory under the international collaboration framework of the MICS-Asia and HTAP. Atmos. Chem. Phys. 2017, 17, 935-963. [CrossRef]

46. Klimont, Z.; Kupiainen, K.; Heyes, C.; Purohit, P.; Cofala, J.; Rafaj, P.; Borken-Kleefeld, J.; Schöpp, W. Global anthropogenic emissions of particulate matter including black carbon. Atmos. Chem. Phys. 2017, 17,8681-8723. [CrossRef]

47. Crippa, M.; Guizzardi, D.; Muntean, M.; Schaaf, E.; Dentener, F.; van Aardenne, J.A.; Monni, S.; Doering, U.; Olivier, J.G.J.; Pagliari, V.; et al. Gridded Emissions of Air Pollutants for the period 1970-2012 within EDGAR v4.3.2. Earth Syst. Sci. Data 2018, 10, 1987-2013. [CrossRef]

48. Lu, Z.; Zhang, Q.; Streets, D.G. Sulfur dioxide and primary carbonaceous aerosol emissions in China and India, 1996-2010. Atmos. Chem. Phys. 2011, 11, e9839-e9864. [CrossRef]

49. Kang, Y.; Liu, M.; Song, Y.; Huang, X.; Yao, H.; Cai, X.; Zhang, H.; Kang, L.; Liu, X.; Yan, X.; et al. High-resolution ammonia emissions inventories in China from 1980 to 2012. Atmos. Chem. Phys. Discuss. 2016, 16, 2043-2058. [CrossRef]

50. Xu, P.; Zhang, Y.; Gong, W.; Hou, X.; Kroeze, C.; Gao, W.; Luan, S. An inventory of the emission of ammonia from agricultural fertilizer application in China for 2010 and its high-resolution spatial distribution. Atmos. Environ. 2015, 115, 141-148. [CrossRef]

51. Wang, S.X.; Zhao, S.Y.; Cai, Z.; Klimont, C.; Nielsen, M.B.; McElroy, T.; Morikawa, T.; Woo, J.H.; Kim, Y.; $\mathrm{Fu}, \mathrm{X}$. Emission Trends and Mitigation Options for Air Pollutants in East Asia. Atmos. Chem. Phys. 2014, 14, 2601-2674. [CrossRef]

52. Zhao, Y.; Zhang, J.; Nielsen, C.P. The effects of energy paths and emission controls and standards on future trends in China's emissions of primary air pollutants. Atmos. Chem. Phys. 2014, 14, 8849-8868.

53. Xia, Y.; Zhao, Y.; Nielsen, C.P. Benefits of China's efforts in gaseous pollutant control indicated by the bottom-up emissions and satellite observations 2000-2014. Atmos. Environ. 2016, 136, 43-53. [CrossRef]

54. GlobEmission. Available online: http://www.globemission.eu/data.php (accessed on 20 January 2019).

55. Wu, R.; Bo, Y.; Li, J.; Li, L.; Li, Y.; Xie, S. Method to establish the emission inventory of anthropogenic volatile organic compounds in China and its application in the period 2008-2012. Atmos. Environ. 2016, 127, $244-254$. [CrossRef]

56. Wang, X.; Situ, S.; Guenther, A.; Chen, F.; Wu, Z.; Xia, B.; Wang, T. Spatiotemporal variability of biogenic terpenoid emissions in Pearl River Delta, China, with high-resolution land-cover and meteorological data. Tellus B. 2011, 63, 241-254. [CrossRef]

57. Fu, Y.; Liao, H. Simulation of the interannual variations of biogenic emissions of volatile organic compounds in China: Impacts on tropospheric ozone and secondary organic aerosol. Atmos. Environ. 2012, 59, 170-185. [CrossRef]

58. Stavrakou, T.; Muller, J.-F.; Bauwens, M.; De Smedt, I.; Van Roozendael, M.; Guenther, A.; Wild, M.; Xia, X. Isoprene emissions over Asia 1979-2012: Impact of climate and land-use changes. Atmos. Chem. Phys. 2014, 14, 4587-4605. [CrossRef]

59. Klinger, L.F.; Li, Q.; Guenther, A.B.; Greenberg, J.P.; Bai, J.; Baker, B. Assessment of volatile organic compound emissions from ecosystems of China. J. Geophys. Res. Atmos. 2002, 107, 4603. [CrossRef]

60. van der Werf, G.R.; Randerson, J.T.; Giglio, L.; van Leeuwen, T.T.; Chen, Y.; Rogers, B.M.; Mu, M.; van Marle, M.J.E.; Morton, D.C.; Collatz, G.J.; et al. Global fire emissions estimates during 1997-2016. Earth Syst. Sci. Data 2017, 9, 697-720. [CrossRef]

61. GFED. Available online: http://www.geo.vu.nl/ \{\}gwerf/GFED/GFED4/tables/ (accessed on 20 May 2020).

62. Kaiser, J.W.; Heil, A.; Andreae, M.O.; Benedetti, A.; Chubarova, N.; Jones, L.; Morcrette, J.-J.; Razinger, M.; Schultz, M.G.; Suttie, M.; et al. Biomass burning emissions estimated with a global fire assimilation system based on observed fire radiative power. Biogeosciences 2012, 9, 527-554. [CrossRef]

63. Henrot, A.-J.; Stanelle, T.; Schröder, S.; Siegenthaler, C.; Taraborrelli, D.; Schultz, M.G. Implementation of the MEGAN (v2.1) biogenic emission model in the ECHAM6-HAMMOZ chemistry climate model. Geosci. Model Dev. 2017, 10, 903-926. [CrossRef]

64. Woo, J.-H.; Bu, C.; Kim, J.; Ghim, Y.S.; Kim, Y. Analysis of Regional and Inter-annual Changes of Air Pollutants Emissions in China. J. Korean Soc. Atmos. Environ. 2018, 34, 87-100. [CrossRef] 
65. Zheng, B.; Tong, D.; Li, M.; Liu, F.; Hong, C.; Geng, G.; Li, H.; Li, X.; Peng, L.; Qi, J.; et al. Trends in China's anthropogenic emissions since 2010 as the consequence of clean air actions. Atmos. Chem. Phys. 2018, 18, 14095-14111. [CrossRef]

(9) (C) 2020 by the authors. Licensee MDPI, Basel, Switzerland. This article is an open access article distributed under the terms and conditions of the Creative Commons Attribution (CC BY) license (http://creativecommons.org/licenses/by/4.0/). 